\title{
Morphological Investigation of Innominate Bones from Pleistocene in Japan with Special Reference to the Akashi Man
}

\author{
Banri $\mathrm{ENDO}^{1)}$ and Hisao $\mathrm{BABA}^{2)}$ \\ 1) Department of Anthropology, Faculty of Science, \\ The University of Tokyo \\ 2) Department of Anatomy, Dokkyo University School \\ of Medicine
}

\begin{abstract}
All the human male innominate bones seemingly from the Pleistocene age were morphologically investigated based on the recent advances in knowledge. New measurement methods were applied to these innominates as well as the available fossil innomimate casts and Recent Japanese innominates for comparison. For this measurement and observation new casts were made from all the fossils and restored so as to presume the whole form of the ilium. Some of the multivariate analyses were used for the objective comparison. The results indicate that the Akashi man is comparable neither to Erectus nor to Neanderthal nor to Pleistocene Sapiens but to modern Sapiens, whereas the Minatogawa man and the Mikkabi man are in many respects archaic and seem certain to be the Pleistocene Sapiens.
\end{abstract}

\section{INTRODUCTION}

Human skeletal remains from the Pleistocene age are rather poor in Japan. They are mostly fragments of various bones except in the case of the Minatogawa man. However, there are several innominate bones among them. Some of these bones are available for morphological study. They have actually been studied, but these studies carried out some decades ago, do not seem to be appropriate from the viewpoint of recent knowledge. Furthermore, the oldest finding, named Akashi, is the most famous, but it was collected in a clod dropped from the wall of a cliff which consisted of outcrops of

This paper is dedicated to Emeritus Professor Hisashi SuzUk of the University of Tokyo in commemoration of his seventieth birthday.
Pleistocene and Holocene deposits. Thus it left a stratigraphical doubt and, later on, a morphological one as well.

The innominate bone among the postcranial bones shows the most remarkable change during human evolution. Therefore, it is important to investigate thoroughly the Japanese Pleistocene innominates based on recent advances in knowledge.

The present paper aims in this respect to examine these innominate bones comparing them with those of recent and prehistoric Japanese as well as with those from the Pleistocene age around the world in each stage of human evolution.

\section{MATERIALS}

Preparation of Fossil Specimen

In order to study the form of the in- 
nominate bone in detail, it is desirable to use intact bones or their casts, and it is desirable that they are complete in form. However, it is impossible to obtain complete fossil innominates from Pleistocene. Therefore the fossil innominates were carefully restored where possible to presume the whole form of the ilium and the ischial body.

For this purpose new casts were taken from the fossil innominates or their casts. The restoration was carried out on these new casts. These casts were made of yellow gypsum and white gypsum was used for the restoration.

It is important for the comparative study of the fossils to observe various fossil casts of the same color. Otherwise, the proper color of fossil or cast often misleads the morphological observation.

\section{Selection of Specimen}

Only male innominates were used in the case of Japanese specimen, because, as is often described, the male bone shows more marked stage-specific characters than the female.

The available Japanese specimens and casts of the fossil hominid were mainly left. Therefore, the comparison was done in left innominates.

Innominates from Pleistocene in Japan

Innominate bones found in Japan apparently from the Pleistocene deposits are as follows :

\section{Akashi}

A male left innominate without the pubis (Plate 4). A part of the ilium is broken off. It was discovered by NAORA, a geologist, at Akashi, Western Japan. He found it in a clod dropped onto a terrace near the seashore from the wall of a cliff which consisted of outcrops of a series of Pleistocene and Holocene deposits. Considering from the nature of the clod, he maintained that the bone had been in a Pleistocene deposit (NAORA, 1936). The morphological features of this bone were reported by HASEBE (1948). He concluded that this bone was different from that of Homo sapiens. This bone was destroyed during the Second World War. Only a few casts remain. Afterwards, the wall was excavated but there were no findings at all. Examinations of the deposits and of the artifact-like stones were carried out. Many doubts arose from these examinations (reviewed by WATANABE, 1970).

\section{Mikkabi}

An anterior part of a male right ilium with upper part of the acetabulum (Plate 5). It was found in 1959 in a fissure deposit from the Pleistocene age in a limestone quarry at Mikkabi, Central Japan. This bone was discoverd by a worker of the quarry, who had been asked by SUzUKI and TAKAI, anthropologist and paleontologist respectively, to find fossil bones and to observe the deposits which yielded these bones. Excavation and geological investigation organized by them were carried out in a month after this discovery. Several human bones were uncovered together with many mammalian fossils during this excavation. The results of this field work and related laboratory studies were reported by SUzUKI 


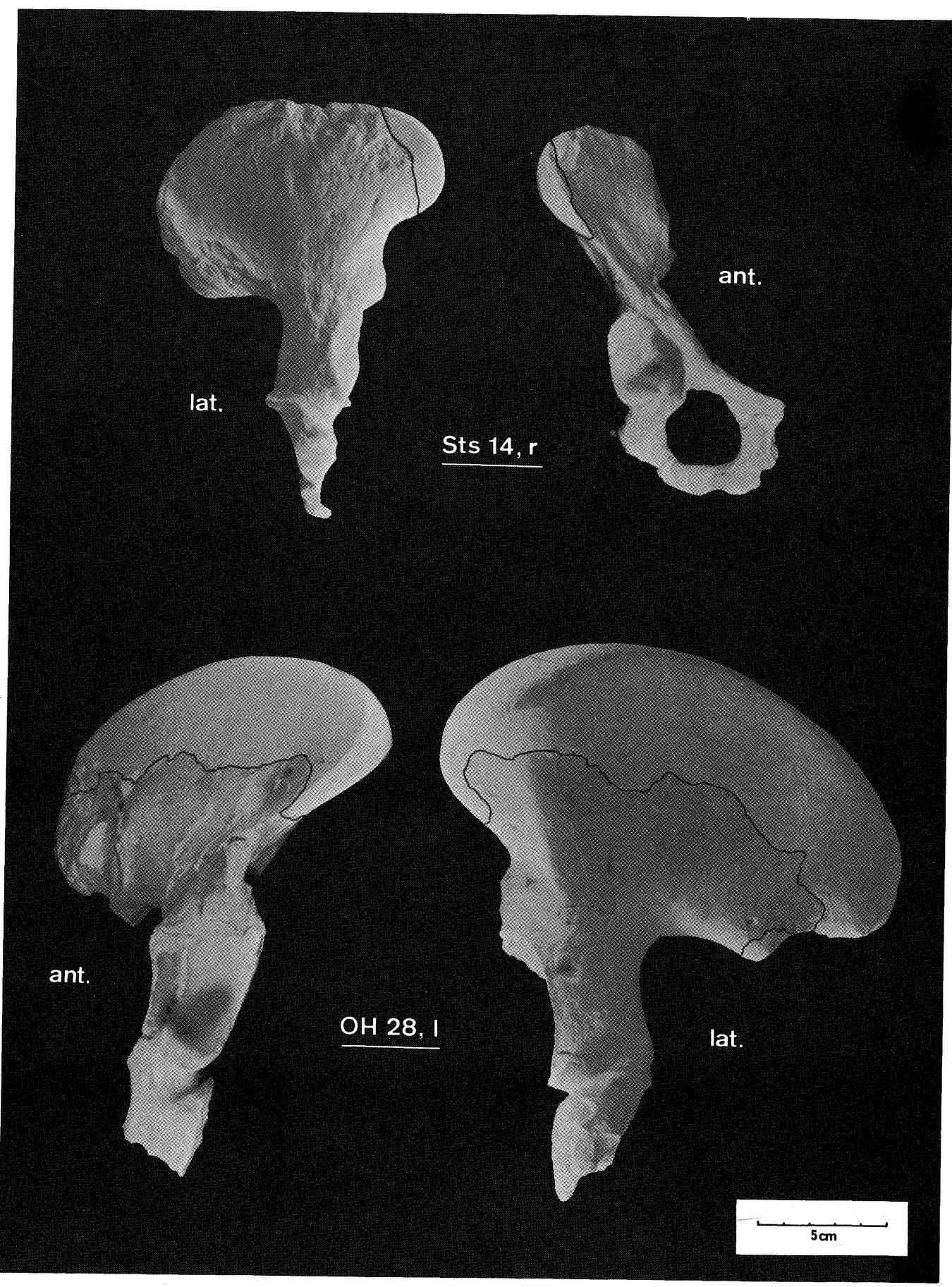

Plate 1. Restored casts of right innominate of Sts-14 and left innominate of OH-28. 


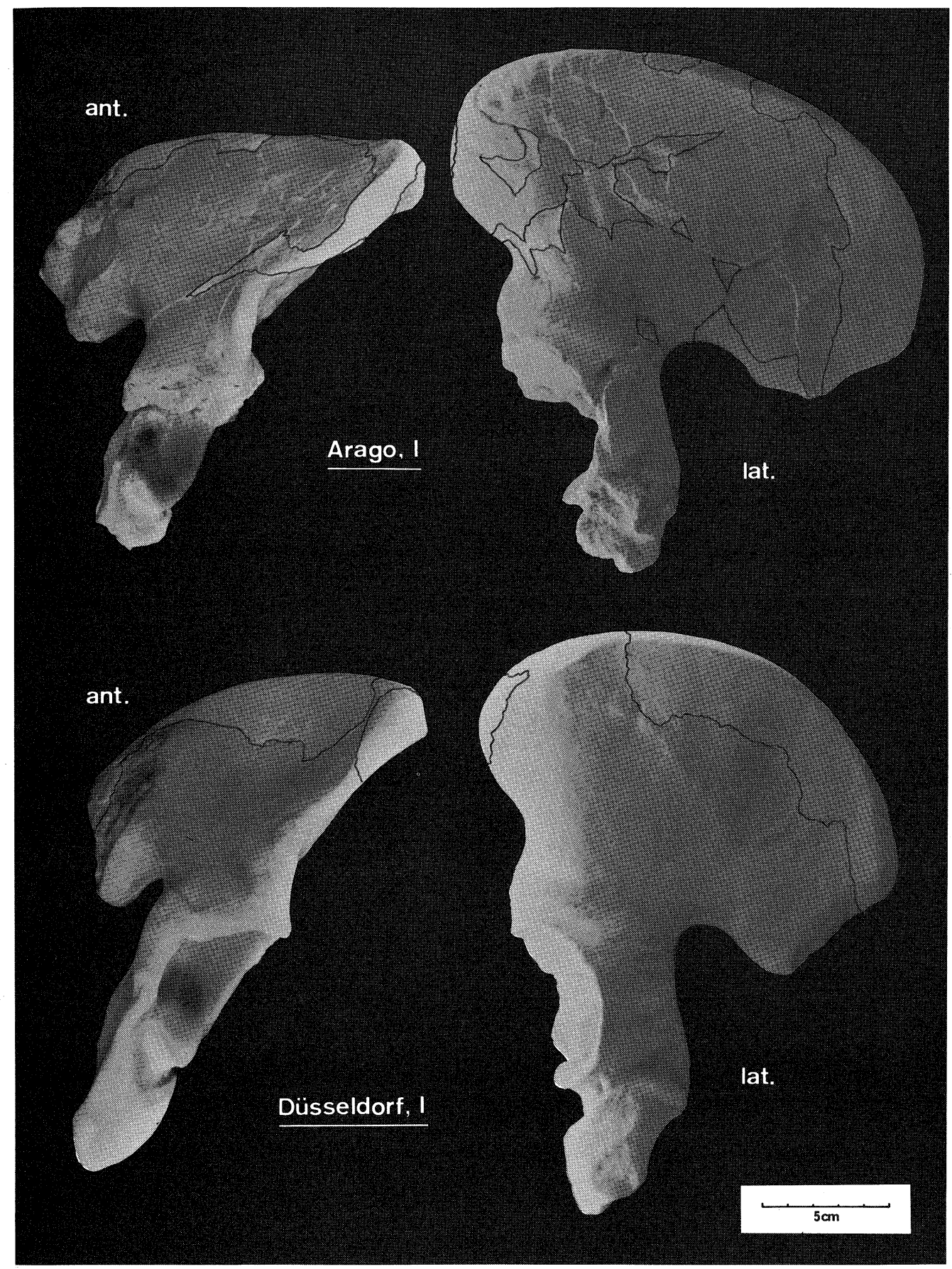

Plate 2. Restored casts of left innominates of Arago and Düsseldorf. 


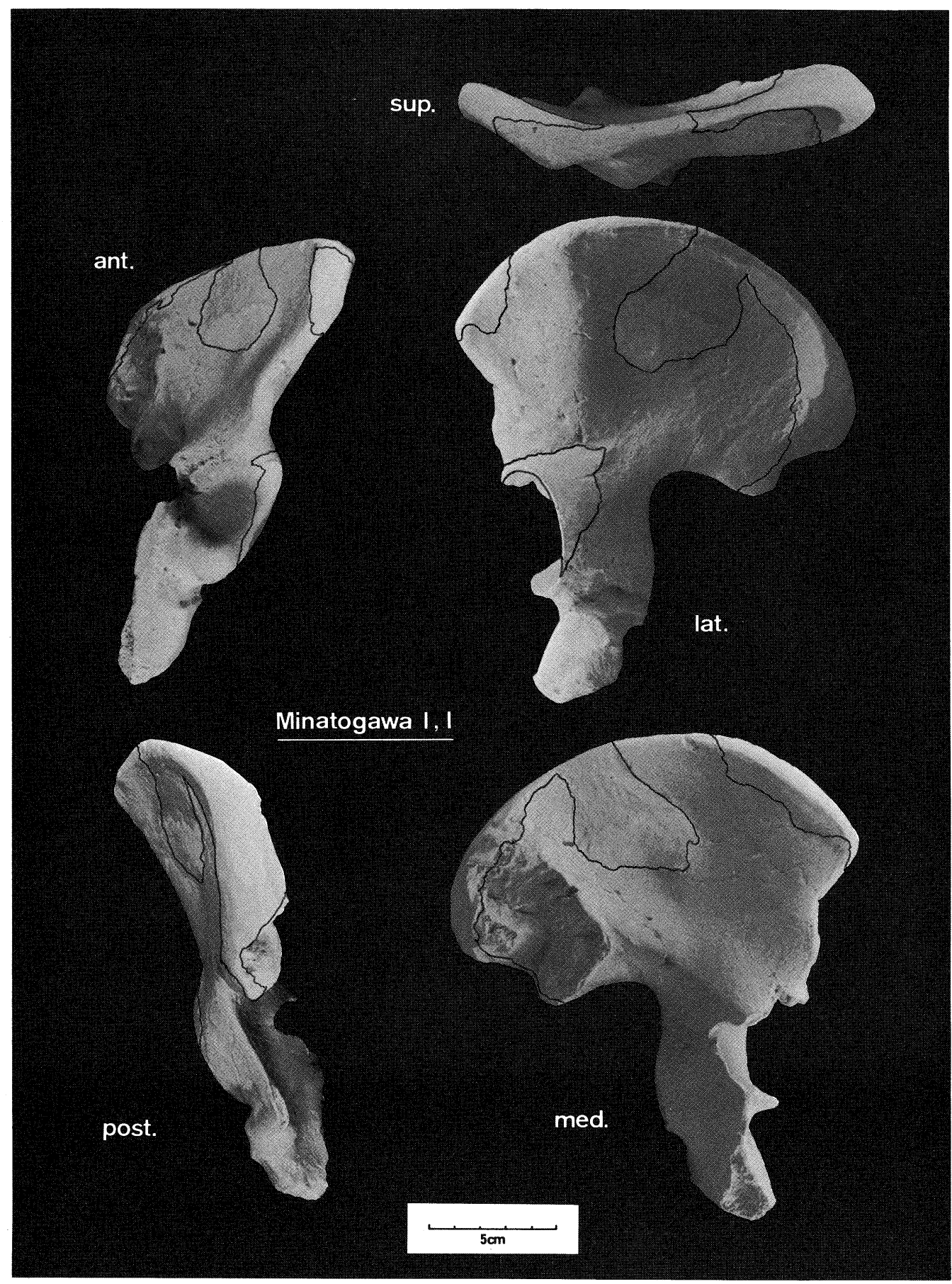

Plate 3. Restored cast of left innominate of Minatogawa I. 


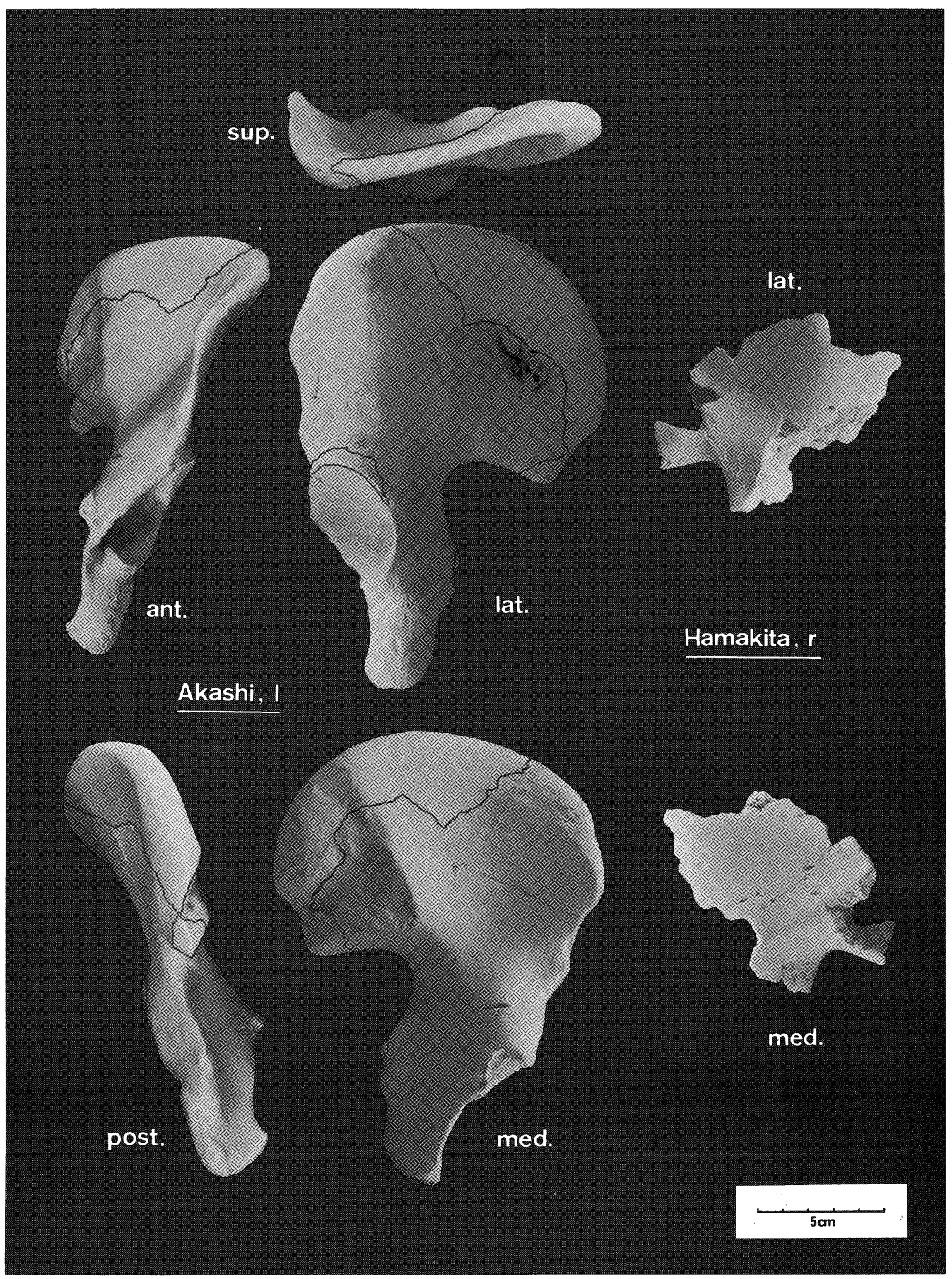

Plate 4. Restored cast of left innominate of Akashi and cast of right innominate fragment of Hamakita. 


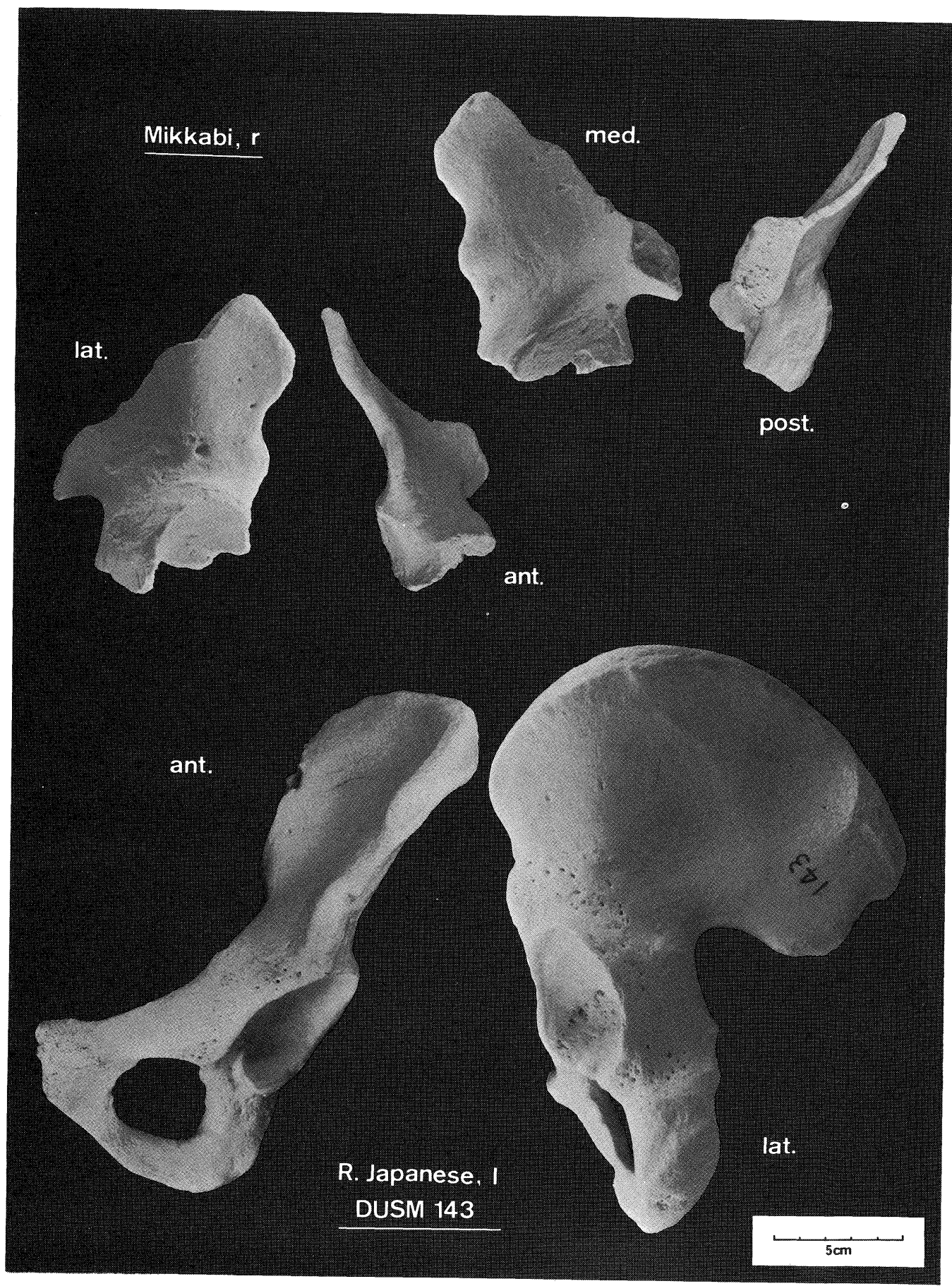

Plate 5. Cast of right innominate fragment of Mikkabi and left innominate of a Recent Japanese. 


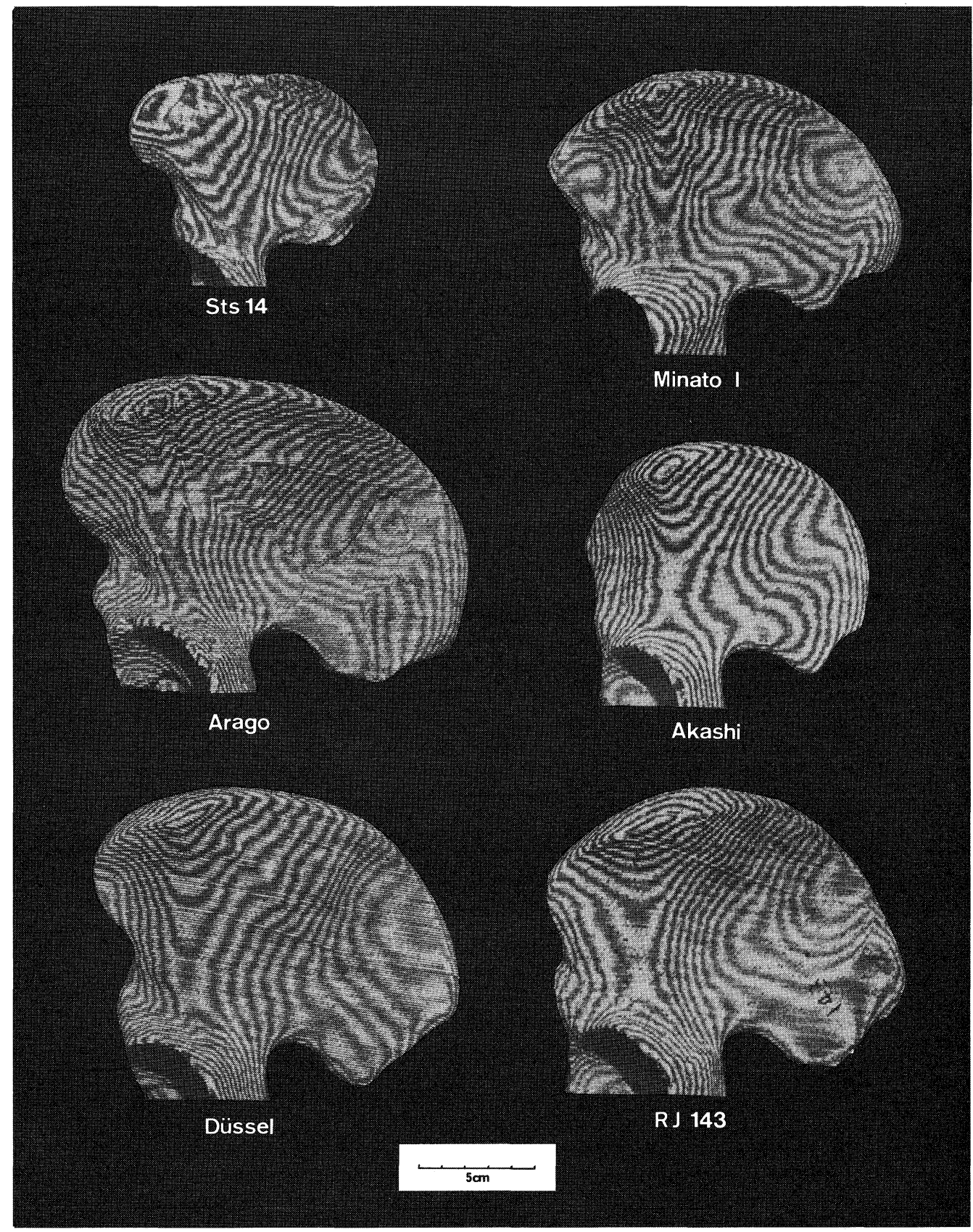

Plate 6. Parallel light moiré contourograms of ilia used in the present study. Left, from top to bottom, Australopithecus, Erectus and Neanderthal; right, upper two are from Pleistocene in Japan and bottom, Recent Japanese. The illium is so held that the line between anterior inferior spine and posterior inferior spine and the line between the top of the tubercle of iliac crest and the top of the acetabular brim are approximately orthogonal to the direction of the lens of camera, Height interval of fringe is $2 \mathrm{~mm}$. 
et al (1962).

\section{Hamakita}

A fragment of a female right ilium around the greater sciatic notch (Plate 4). It was found in 1960 in a cave deposit of a limestone quarry at Hamakita, Central Japan. It was uncovered by workers of the quarry who were also asked by SUzUKI and TAKAI to do the same as in the case of Mikkabi. In 1962 and 1963, excavations and geological surveys organized by them were carried out. Studies on this site and on discoveries were reported by Suzuki et al (1966).

Minatogawa $I, I I, I I I, I V$

Four individual skeletons remain together with a number of bones from unknown individuals. They have more or less broken innominates of both sides. I is male and others are female. These fossils were collected in a limestone quarry at Minatogawa, island of Okinawa, by Oунма, a so-called amateur paleontologist living in Okinawa, from 1968 to $1974 . \quad$ Excavations and geological surveys were organized by Suzuki and carried out in 1968 and 1969. Studies of human fossils and of geology were pulished by SuzUKi et al (1982). The left innominate of Minatogawa $I$ is shown in Plate 3.

\section{Innominates of Recent and Prehistoric Japanese}

The standardized metrical characters of Japanese for comparison were obtained from the published data on recent male Japanese in the Kinai region where is near the locality of Akashi (Miунмото, 1927), and the data of the male skeleton excavated at the Tsukumo site from the prehistoric Jomon age where is also near the locality of Akashi (TABATA, 1928).

For further comparison of detailed characters it is necessary to use intact bones. In this respect twelve left innominates of recent Japanese males were selected at random from the skeletal collections stored in the Department of Medicine of the University Museum, The University of Tokyo and in the Department of Anatomy of the Dokkyo University School of Medicine. They consisted of No. 2138, No.2156, No.2159, No. 2177, No. 2178, No. 2390, No.2394, No. 2547 and No. 2593 from the former and No. 54, No. 129 and No. 143 from the latter.

\section{Cast of Innominate of Fossil Hominid}

In order to compare many detailed characters with fossil hominid innominates it is necessary to use their casts, though their number becomes limited. The cast of fossil hominids used in the present study were as follows:

\section{Australopithecus stage}

[Sts-14] Right innominate, discovered at Sterkfontain in South Africa during 19361949. It has been described by many authors. The cast was obtained from the Wenner-Gren Foundation (Plate 1).

\section{Erectus stage}

[OH-28] Left innominate, discovered at Olduvai Gorge in Tanzania in 1970 and reported by Leakey (1971) and DAy (1971). The cast was obtained from the National Museums of Kenya (Plate 1).

[Arago]* Left innominate, discovered at 
Arago, Tautaval in France in 1978 and reported by de Lumley (1979). The cast was given by Professor de LumLey to the University Museum of The University of Tokyo (Plate 2).

\section{Neanderthal Stage}

[Düsseldorf] Left innominate, originally named "Neandertal" but called Düsseldorf in the present paper in order to distinguish it from the name of stage. It was discovered at Neandertal in Germany in 1856 and reported by FUHLROTT and SchaAfFHAUSEN (1857). The cast used in the present study was stored in the Medical Museum of The University of Tokyo (Plate 2).

\section{GENERAL VIEW}

\section{Form in general}

As seen in Plates 4 and 5, Hamakita
Innominate is such a small fragment that morphological observation is impossible, while the bone of Mikkabi is fragmental but observation is possible as to the anterior part of the ilium. The innominates of Akashi and Minatogawa I are sufficient for the purpose of observation of the ilium and the ischial body, as seen in Plates 3 and 4.

It seems at a glance that Akashi innominate is similar neither to Neanderthal nor to Erectus nor to Australopithecus but to the Recent Japanese. This bone seems also different from the innominate of Minatogawa I. The bone of Minatogawa I seems relatively similar to the Recent Japanese but also somewhat similar to Düsseldorf.

The innominate of Akashi seems generally smaller than the usual recent or

Table 1. Standardized metrical characters of innominate bones used in the present study.

\begin{tabular}{|c|c|c|c|c|c|c|c|c|}
\hline $\begin{array}{c}\begin{array}{c}\text { Item with } \\
\text { MARTIN's } \\
\text { Number }\end{array} \\
\text { Specimens }\end{array}$ & $\begin{array}{l}\text { (1) } \\
\text { Height } \\
\text { of } \\
\text { Pelvis }\end{array}$ & $\begin{array}{l}\text { (9) } \\
\text { Height } \\
\text { of. } \\
\text { Ilium }\end{array}$ & $\begin{array}{l}\text { (12) } \\
\text { Width } \\
\text { of } \\
\text { Ilium }\end{array}$ & $\begin{array}{l}(9: 12) \\
\text { Height- } \\
\text { Width } \\
\text { Index } \\
\text { of } \\
\text { Ilium }\end{array}$ & $\begin{array}{l}\text { (13) } \\
\text { Width } \\
\text { of } \\
\text { Iliac } \\
\text { Blade }\end{array}$ & $\begin{array}{l}\text { (15) } \\
\text { Height } \\
\text { of } \\
\text { Ischium }\end{array}$ & $\begin{array}{l}(22) \\
\text { Maximum } \\
\text { Diameter } \\
\text { of } \\
\text { Aceta- } \\
\text { bulum }\end{array}$ & $\begin{array}{l}(32: 31) \\
\text { Sciatic } \\
\text { Notch } \\
\text { Index }\end{array}$ \\
\hline \multicolumn{9}{|l|}{ Australopithecus } \\
\hline Sts-14 & - & 99 & (107) & (93) & $(79)$ & (59) & (38) & 48 \\
\hline \multicolumn{9}{|l|}{ Erectus } \\
\hline $\mathrm{OH}-28$ & - & $((139))$ & $((175))$ & $((79))$ & (115) & - & 56 & 69 \\
\hline Arago & - & 144 & (186) & $(77)$ & (114) & - & 59 & 96 \\
\hline \multicolumn{9}{|l|}{ Neanderthal } \\
\hline Düsseldorf & $(230)$ & (148) & (173) & $(86)$ & (115) & (92) & 60 & 87 \\
\hline \multicolumn{9}{|c|}{ Pleistocene Japanese } \\
\hline Minatogawa $\mathrm{I}$ & (195) & 126 & (156) & (81) & 102 & (71) & 48 & (68) \\
\hline Akashi & (182) & 117 & (126) & (93) & 72 & (74) & 48 & 67 \\
\hline \multicolumn{9}{|c|}{ Jomon Age Japanese } \\
\hline Tsukumo $\left({ }^{n}{ }_{M}^{s}\right)$ & $\begin{array}{cc}11 \quad 7.5209 \\
190.8\end{array}$ & $\begin{array}{c}115.4921 \\
130.8\end{array}$ & $\begin{array}{l}9 \quad 6.2805 \\
150.2\end{array}$ & $\begin{array}{l}92.9351 \\
87.4\end{array}$ & $\begin{array}{c}138.3451 \\
90.2\end{array}$ & $\begin{array}{c}14 \quad 4.3959 \\
84.6\end{array}$ & $\begin{array}{c}142.7012 \\
54.3\end{array}$ & $\begin{array}{c}37.8886 \\
61.0\end{array}$ \\
\hline \multicolumn{9}{|l|}{ Recent Japanese } \\
\hline Kinai $\quad\left(\begin{array}{ll}n & s \\
M\end{array}\right)$ & $\begin{array}{l}309.6773 \\
191.1\end{array}$ & $\begin{array}{l}306.3608 \\
127.4\end{array}$ & $\begin{array}{l}306.3428 \\
147.9\end{array}$ & $\begin{array}{c}302.5746 \\
84.5\end{array}$ & $\begin{array}{l}304.5674 \\
88.6\end{array}$ & $\begin{array}{l}304.5708 \\
82.7\end{array}$ & $\begin{array}{c}30 \quad 2.2581 \\
53.7\end{array}$ & $\begin{array}{c}30 \\
\quad 68.0740 \\
68.0\end{array}$ \\
\hline
\end{tabular}


prehistoric Jomon Japanese innominates and its ilium seems relatively higher and narrower than the latter. The standardized metrical characters show these tendencies as seen in Table 1. However, objective conclusion must be obtained from statistical analysis.

Statistical analysis

Usually it is desirable for the numerical analysis of bone morphology to use the standardized metrical characters described in MARTIN's textbook. However, those metrical characters available for the fossil specimens concerned are rather limited, representing only simple heights or widths. A principal component analysis carried out of those characters excluding indices seen in Table 1 indicates strong influence of size factor over all characters, though some other minor factors can be

Table 2. Component loadings obtained from the principal compoment analysis of the thirty Recent Kinai Japanese males.

\begin{tabular}{lcrr}
\hline Principal Component & I & II & III \\
\hline Eigenvalue & 4.598 & 0.519 & 0.371 \\
Cumulative Proportion & 0.766 & 0.853 & 0.915 \\
\hline (Component Loading) & & & \\
1. Height of pelvis & 0.915 & -0.216 & -0.258 \\
9. Heighs of ilium & 0.933 & 0.062 & -0.160 \\
12. Width of ilium & 0.863 & 0.154 & 0.403 \\
13. Width of iliac blade & 0.793 & 0.515 & -0.213 \\
15. Height of ischium & 0.842 & -0.420 & -0.039 \\
22. Max. diameter of acetabulum & 0.898 & -0.053 & 0.267 \\
\hline
\end{tabular}

Table 3. Results of the test for rejection of observed vectors applied to the innominate bones from Japan used in the present study.

\begin{tabular}{lcc}
\hline Population( $(S)$ & \multicolumn{2}{c}{$\begin{array}{c}\text { Recent Kinai Japanese }(n=30) \\
\text { Characters }\end{array}$} \\
& $\begin{array}{l}\text { 9. Height of ilium } \\
\text { 12. Width of ilium } \\
\text { 13. Width of iliac blade } \\
\text { 15. Height of ischium } \\
\text { 22. Max. diameter of acetabulum }\end{array}$ \\
\hline Specimen( $x$ ) & Observed $F$ & Probability $(x \in S)$ \\
\hline Tsukumo 2 & 0.766 & 0.583 \\
Tsukumo 27 & 1.698 & 0.172 \\
Tsukumo 30 & 2.114 & 0.097 \\
Tsukumo 32 & 1.194 & 0.341 \\
Tsukumo 33 & 0.629 & 0.679 \\
Akashi & 3.855 & 0.0125 \\
Minatogawa I & 9.432 & 0.000378 \\
\hline
\end{tabular}


observed, as shown in Table 2. Therefore the statistical analysis of those characters may be favorable for use within a relatively homogeneous population.

Hence, the statistical analysis of those characters is limited to the specimens in Japan. The test for rejection of vectors from a certain vector population (a kind of multivariate analysis) formulated by Masuyama (1943, Note 1) is applied. The objects are Akashi and Minatogawa $I$ as well as five available Tsukumo specimens from the prehistoric Jomon age, while the population is Recent Kinai Japanese innominates. As shown in Table 3, the results reveal that the Akashi specimen, though it is small, is included to the Recent Kinai Japanese together with Tsukumo specimens at a probability of 0.01 , while Minatogawa I is completely rejected. It can be concluded from these facts that the Akashi specimen can be an in- nominate of a very small Recent Japanese or at least of a small individual belonging to any Japanese population from the Holocene prehistoric to the recent age.

A multidimensional scaling, using the shape distance matrix based on the same characters and applied to the same specimens, and 99\% tolerance ellipse of Recent Kinai Japanese computed from this results indicate not only the same conclusion but also the fact that Akashi is far from minatogawa I and considerably distant from Tsukumo men from the prehistoric Jomon age (Fig. 1). When seen from the location of the mean of thirty Recent Kinai men, Akashi is shifted to the direction inverse to Tsukumo and Minatogawa. It is possible to conclude from the results of these analyses that the Akashi innominate is a rather modern one while Minatogawa I specimen is completely different from the Holocene Japanese.

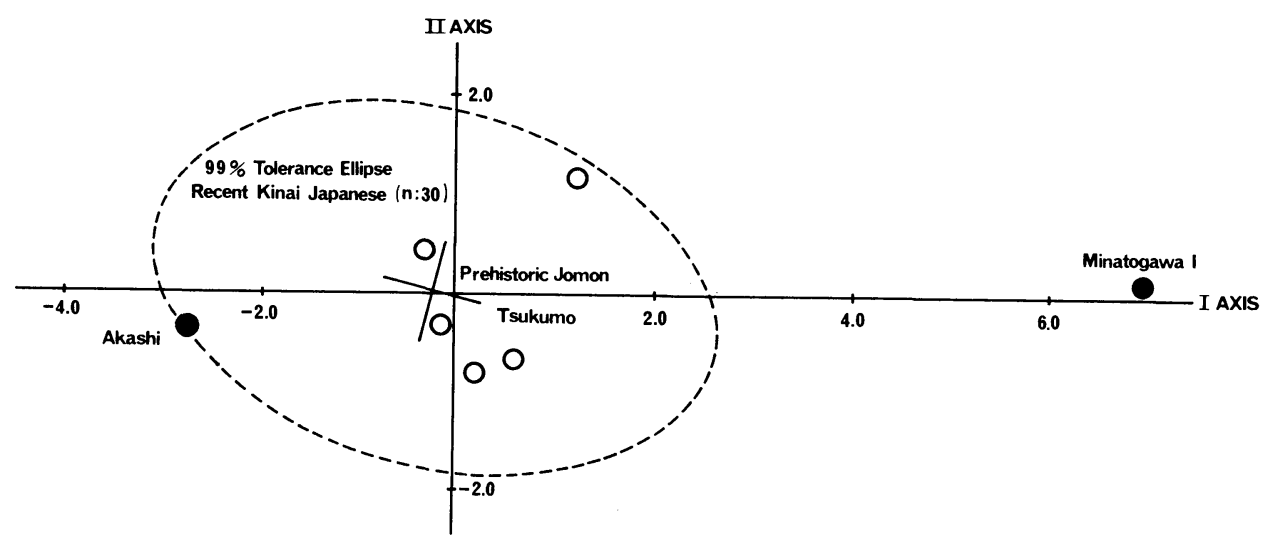

CONTRIBUTION $67.5 \%$

Fig.1. Two-dimensional demonstration of the results obtained from the multidimensional scaling of various innominates from Japan, based on the shape distances using the standard deviations of Recent Kinai Japanese. The normality of the two variables shown of the Recent Kinai Japanese is verified by the $k$-statistics test according to FISCHER (1953) or KISHINE (1977) see Note 2. The tolerance ellipse is made based on this result. 


\section{SURFACE STRUCTURES}

\section{General remarks}

Generally, various structures of the surface can be seen in the case of the innominate bone. They are important in studying the fossil innominate. Because the specimens in the present study are more or less broken, the observable structures are limited. Nevertheless, several structures can be examined on the Japanese fossil specimens in order to compare with fossil hominids from different stages. These structures are generally three-di mensional and hardly quantified. Therefore, their characters are represented by grades as seen in Table 4. Some of these structures are explained as below.

\section{Sigmoid curvature of iliac crest}

The iliac crest seen from above generally shows a sigmoid curvature. McCown and KeITH (1939) pointed out that this curvature is rather weak in Neanderthals and strong in Sapiens. The presumed curvature of the specimens used in the present study are shown in Fig. 2. It is observable that this curvature becomes more pronounced from the Australopithecus stage to the Sapiens stage. In this respect Akashi is a modern Sapiens type. Minatogawa $\mathrm{I}$ is also a Sapiens type but somewhat archaic.

Table 4. Observable surface structures.

\begin{tabular}{|c|c|c|c|c|c|c|c|}
\hline \multirow{3}{*}{$\begin{array}{l}\text { Item } \\
+++: \text { pronounced } \\
++: \text { moderate } \\
+: \text { slight } \\
-: \text { absent }\end{array}$} & \multirow{3}{*}{$\begin{array}{l}\text { Australo- } \\
\text { pithecus } \\
\text { Sts-14 }\end{array}$} & \multirow{2}{*}{\multicolumn{2}{|c|}{ Erectus }} & \multirow{3}{*}{$\begin{array}{r}\text { Neander- } \\
\text { thal } \\
\text { Dussel- } \\
\text { dorf }\end{array}$} & \multirow{2}{*}{\multicolumn{3}{|c|}{ Pleistocene Japanese }} \\
\hline & & & & & & & \\
\hline & & $\mathrm{OH}-28$ & Arago & & $\begin{array}{l}\text { Minato- } \\
\text { gawa I }\end{array}$ & Mikkabi & Akashi \\
\hline $\begin{array}{l}\text { Sigmoid Curvature of } \\
\text { Iliac Crest seen } \\
\text { from above }\end{array}$ & + & & + & ++ & ++ & & $++t$ \\
\hline $\begin{array}{l}\text { Concavity of Anterior } \\
\text { Interspinous } \\
\text { Border }\end{array}$ & +++ & $++t$ & +++ & +++ & ++ & ++ & + \\
\hline $\begin{array}{l}\text { Position of Root of } \\
\text { Vertical Iliac Buttress } \\
\text { Seen from Acetabulum* }\end{array}$ & -- & - & - & \pm & \pm & \pm & + \\
\hline $\begin{array}{l}\text { Elevation of Surface } \\
\text { Ridge of Vertical } \\
\text { Iliac Buttress }\end{array}$ & $\#$ & $+t+$ & +++ & ++ & ++ & + & + \\
\hline $\begin{array}{l}\text { Development } \\
\text { of } \\
\text { Supraacetabular Fossa }\end{array}$ & $+t$ & $++t$ & $+t+$ & ++ & + & + & - \\
\hline $\begin{array}{l}\text { Development of } \\
\text { Iliac Sulcus for } \\
\text { Iliopsoas Muscle }\end{array}$ & + & ++ & $+t+$ & $++t$ & ++ & $++t$ & + \\
\hline $\begin{array}{l}\text { Angulation between } \\
\text { Inner Surfaces of } \\
\text { Ilium and Ischium }\end{array}$ & +++ & ++ & +++ & +++ & ++ & ++ & + \\
\hline
\end{tabular}

$*:+=$ anterior, $\pm=$ middle, $-=$ posterior, $--=$ far posterior

\#: not identically comparable 
Anterior superior iliac spine and inter- this notch gradually seem to decrease from spinous notch the Australopithecus stage to the Sapiens

As shown in Fig. 3, there are two paralstage. All the Japanese innominates from lel tendencies, in that the roundness of the Pleistocene are Sapiens type in this reanterior superior spine and the depth of spect.

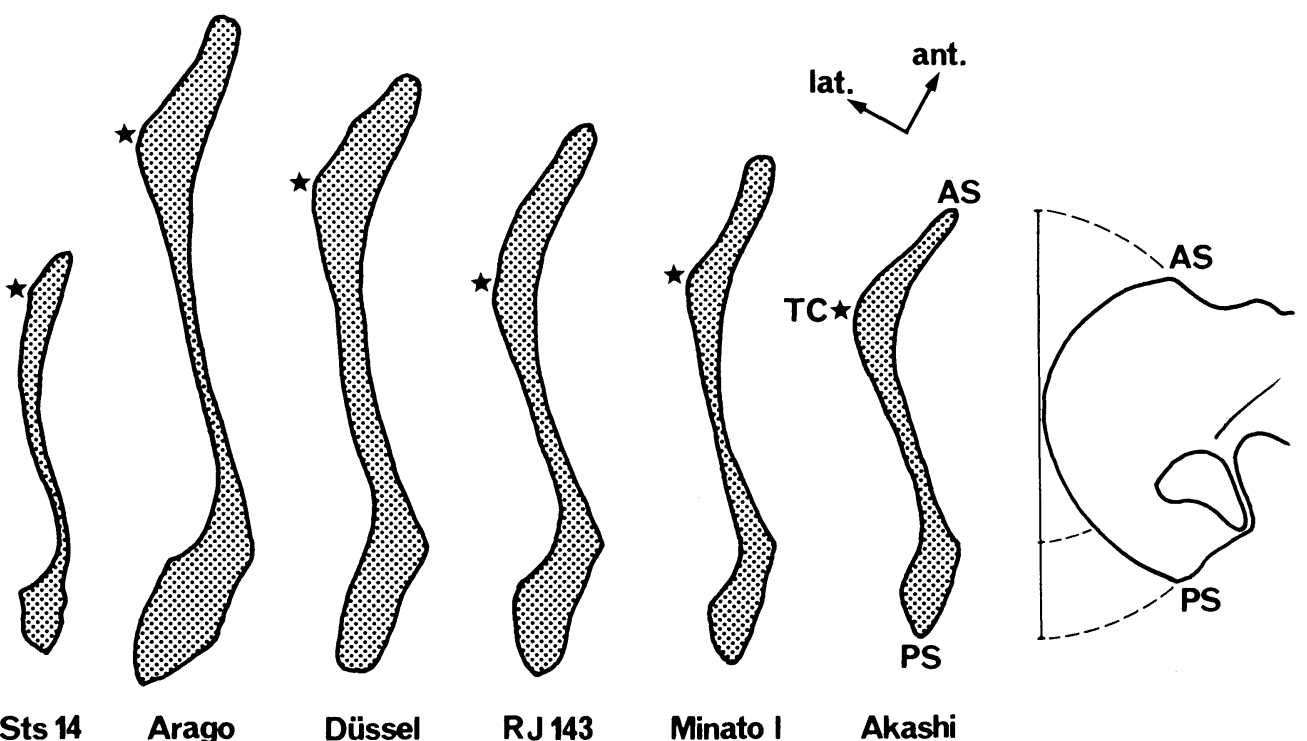

Sts 14 Arago Düssel RJ 143 Minato I Akashi

Fig.2. Presumed sigmoid curvatures of the iliac crest of the left innominate, when seen from above along the iliac crest. The right innominate of Sts-14 is inverted for comparison. TC, tubercle of crest; AS, anterior superior spine; PS, posterior superior spine.

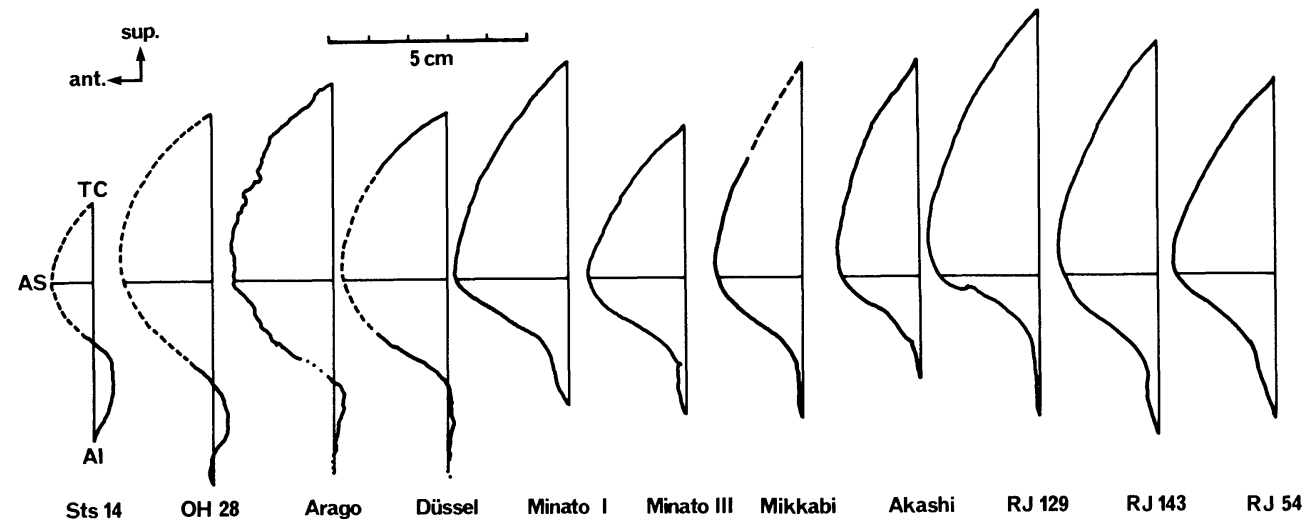

Fig 3. Shape of the anterior border of the ilium. The contour was drawn from the tubercle of crest (TC) via anterior superior spine(AS) to anterior inferior spine. Note the $\mathrm{S}$ shape in Australopithecus and Erectus ( $\mathrm{Sts}-14, \mathrm{OH}-28$, Arago) showing marked contrast to the dog-leg shape in Sapiens (Minatogawa, Mikkabi, Akashi Recent Japanese). 
Tubercle of iliac crest

When the ilium is observed from above, a tubercle can be seen at the anterior turning point of the sigmoid curvature. This tubercle is anteriorly located in Australopithecus and relatively posteriorly in Sapiens according to RoBINSON (1972). The backward shift of this tubercle is obvious from the Australopithecus stage to the Sapiens stage, as seen in
Plate 6 and Fig. 2. This fact indicates that Akashi and Minatogawa I are both Sapiens.

\section{Vertical iliac buttress}

Generally a bony elevation can be seen on the lateral surface of the ilium from the tubercle of the iliac crest to the region of the acetabulum. This long elevation was called the "vertical iliac bar" by McCown and KeIth (1939) and
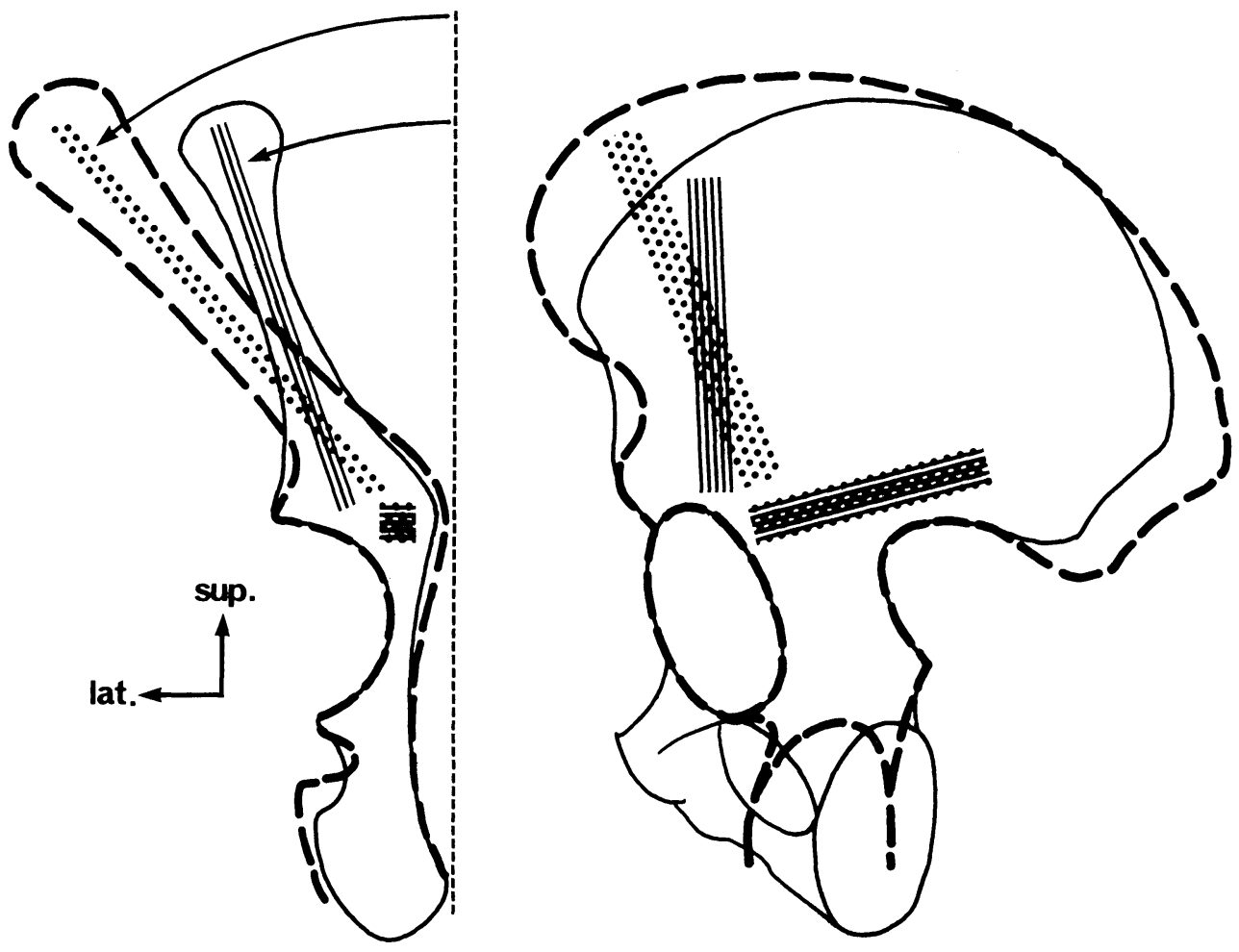

\section{Outline}

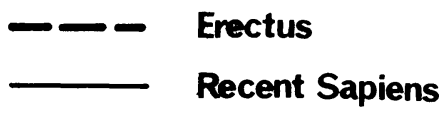

Vertical iliac buttress

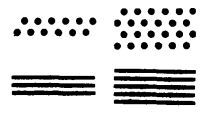

Horizontal iliac bar

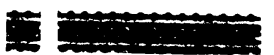

Fig.4. Scheme of the position and inclination of the vertical iliac buttress and the horizontal iliac bar in Erectus and Recent Sapiens. Left, frontal section; right, lateral iliac view. Note the differences in the intersecting point of the vertical iliac buttress and the horizontal iliac bar and in the lateral cant of the iliac blade. 
the "vertical iliac buttress" by ENDO and as shown in Fig.5. Only Akashi is also KIMURA (1970). This is equivalent to the modern in this respect.

"acetabulo-cristal buttress" named by Structures in general

RoBINSON (1972). Its upper end is always Judging from all the structures listed identical to the tubercle, but the lower in Table 4, it is concluded that the all end is different according to the evolu- Japanese specimens are in the Sapiens tionary stage. A comparison of this but- stage and Akashi seems very modern. No tress between Erectus and Sapiens is schematically shown in Fig. 4 . As seen in Table 4, Akashi is modern while Minatogawa I and Mikkabi are rather archaic.

\section{Supraacetabular fossa}

A marked development of this fossa was first observed by Boul (1911-13) in Neanderthals. This fossa is more developed in the Erectus stage as seen in Table 4. Its development also shows that Akashi is modern while Minatogawa I and Mikkabi are somewhat archaic. The presence of this fossa influences the shape of the profile of the vertical iliac buttress characters indicating the earlier stage can be seen in the case of Akashi innominate bone.

\section{Detailed metrical characters}

For further objective comparison in detail, a series of metrical methods was developed as shown in the explanation of Fig.6. Measurements were carried out on fossil specimens and on twelve Recent Japanese specimens.

The results thus obtained are shown in Tables 5 and $6 . \quad$ The inclinations of the

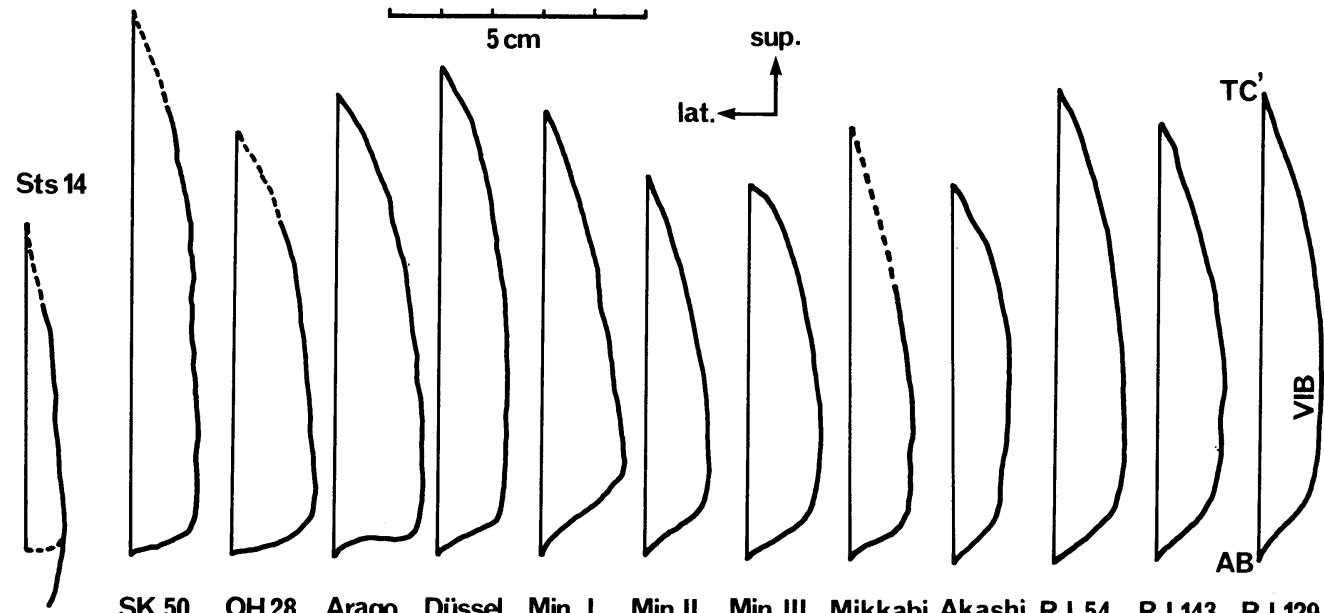

SK 50 OH 28 Arago Düssel Min I Min II Min III Mikkabi Akashi RJ 54 RJ 143 RJ 129

Fig.5. Profiles of the ridge of the vertical iliac buttress. Setting the plane of the acetabular brim vertically and the vertical buttress horizontally, the profile of the buttress is drawn from the lateral corner of the tubercle of crest $\left(\mathrm{TC}^{\prime}\right)$, along the ridge of the buttress, to the edge of the acetabular brim (AB) by means of the diagraph. 


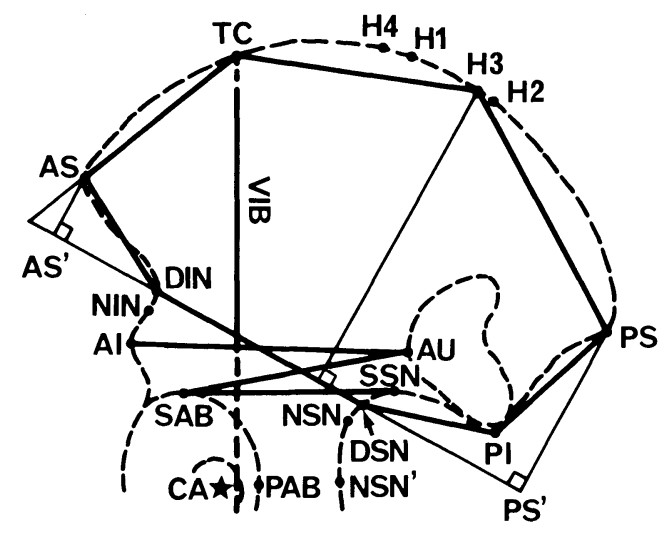

Fig.6. Measurements of the ilium.

Setting the iliac blade horizontally, outlines of the ilium are plotted by the perigraph and the following points for measurement are projected by the diagraph onto a sheet of paper.

TC: The point on the tubercle of the crest at which the ridge of the crest and the extension of the ridge of the vertical iliac buttress (VIB) intersect with each other.

AS: Center of the anterior superior spine.

$\mathrm{AS}^{\prime}$ : Foot of the perpendicular from AS on the extension of DIN-DSN line.

DIN : Deepest point of the interspinous notch. NIN: The point on the interspinous notch nearest to the greater sciatic notch.

$A I$ : Center of the anterior inferior spine.

SAB: Superior corner of the acetabular brim.

CA: Center of the acetabulum.

PAB: Posterior corner of the acetabular brim.

PS: Center of the posterior superior spine.

$\mathrm{PS}^{\prime}$ : Foot of the perpendicular from PS on the extension of DIN-DSN line.

PI: Center of the posterior inferior spine.

AU: Auricular point; a point of intersection of the arcuate line with the margin of the auricular surface.

SSN : Superior corner of the greater sciatic notch.

DSN : Deepest point of the greater sciatic notch.

NSN: The point on the greater sciatic notch nearest to the interspinous notch.

$\mathrm{NSN}^{\prime}$ : The point on the greater sciatic notch nearest to the acetabular brim.

$\mathrm{H} 1, \mathrm{H} 2, \mathrm{H} 3, \mathrm{H} 4$ : Highest points on the iliac crest measured from the lines of AS-PS,
AS-PI, DIS-DSN, AI-PI respectively.

VIB: Outer ridge of the vertical iliac buttress.

The simplified shape of the heptagon consisting of connecting lines of TC-AS-DINDSN-PI-PS-H3-TC indicates the general shape of the iliac blade and connecting lines of AI-AU-SAB-SSN forms a Z-shaped datum.

Measurements listed below are executed on the paper or directly on the specimen.

i. Height of iliac blade. Length of perpendicular from H3 to DIN-DSN line. Measured on the paper.

ii. Projected width of iliac blade. Distance between $\mathrm{AS}^{\prime}$ and $\mathrm{PS}^{\prime}$ measured on the paper.

iii. Width of iliac blade base. Distance between NIN and NSN.

iv. Width of jliac blade base. Distance beween AI and NSN.

v. Acetabulo-auricular length. Smallest distance between $A U$ and the articular surface of the acetabulum.

vi. Thickness of ischial body. Distance between $\mathrm{PAB}$ and $\mathrm{NSN}^{\prime}$.

vii. Inclination angle of VIB to AI-AU line. Measrued on the paper.

viii. Inclination angle of VIB to SAB-SSN line. Measured on the paper.

ix. Inclination angle of VIB to SAB-AU line. Measured on the paper.

$x$. Inclination angle of VIB to DIN-DSN line. Measured on the paper.

xi. Angle between TC-AS line and DIN-DSN line. Measured on the paper.

xii. Lateral cant angle between AI-axis and AI-AS ridge. Angle between the longest axis of the anterior inferior spine and the line connecting AI and AS. Measured in the frontal plane.

xiii. Lateral cant angle between AI-axis and VIB. Measured in the frontal plane.

xiv. Lateral cant angle between plane of greater sciatic notch and VIB. Angle between the plane formed by the greater sciatic notch and the line of VIB. Measured in the frontal plane. 
Table 5. Detailed metrical characters of the innominates of fossil hominids obtaind by the methods developed for the present study.

\begin{tabular}{|c|c|c|c|c|c|}
\hline Item & & $\begin{array}{l}\text { Australopithecus } \\
\text { Sts } 14\end{array}$ & $\begin{array}{l}\text { Erectus } \\
\text { OH } 28\end{array}$ & $\begin{array}{l}\text { Erectus } \\
\text { Arago }\end{array}$ & $\begin{array}{l}\text { Neanderthal } \\
\text { Düsseldorf }\end{array}$ \\
\hline & $\begin{array}{l}\text { i. Height of Iliac Blade } \\
\text { (H3 to DIN-DSN Line) }\end{array}$ & 72 & (108) & 108 & 102 \\
\hline & $\begin{array}{l}\text { Projected Width of Ilium } \\
\left(\mathrm{AS}^{\prime}-\mathrm{PS}^{\prime}\right)\end{array}$ & 110 & 173 & 185 & 171 \\
\hline i : ii. & $\begin{array}{l}\text { Height-Width Index of } \\
\text { Iliac Blade }\end{array}$ & 65 & 62 & 58 & 60 \\
\hline & $\begin{array}{l}\text { Width of Iliac Blade Base } \\
\text { (NIN-NSN) }\end{array}$ & 45 & 68 & 73 & 72 \\
\hline & $\begin{array}{l}\text { Width of Iliac Blade Base } \\
\text { (AI-NSN) }\end{array}$ & 44 & 69 & 73 & 71 \\
\hline iii : 12 . & $\begin{array}{l}\text { Index of Constriction of } \\
\text { Iliac Blade Base }\end{array}$ & 42 & 39 & 39 & 42 \\
\hline & $\begin{array}{l}\text { Acetabulo-auricular } \\
\text { Length }\end{array}$ & 38 & 47 & 63 & 64 \\
\hline & $\begin{array}{l}\text { Thickness of Ischial } \\
\text { Body(PAB-NSN })\end{array}$ & 22 & 36 & 38 & 38 \\
\hline vii. & $\begin{array}{l}\text { Inclination Angle of VIB } \\
\text { to AI-AU Line }\end{array}$ & 117 & 110 & 109 & 96 \\
\hline viii. & $\begin{array}{l}\text { Inclination Angle of VIB } \\
\text { to SAB-SSN Line }\end{array}$ & 119 & 105 & 108 & 97 \\
\hline & $\begin{array}{l}\text { Inclination Angle of VIB } \\
\text { to SAB-AU Line }\end{array}$ & 104 & 101 & 101 & 88 \\
\hline & $\begin{array}{l}\text { Inclination Angle of VIB } \\
\text { to DIN-DSN Line }\end{array}$ & 155 & 136 & 134 & 126 \\
\hline$(v i i+v i$ & $\begin{array}{l}\mathrm{iii}+\mathrm{ix}) / 3 \text {. Average } \\
\text { Inclination Angle of VIB }\end{array}$ & 113 & 105 & 106 & 95 \\
\hline & $\begin{array}{l}\text { Angle between TC-AS Line } \\
\text { and DIN-DSN Line }\end{array}$ & (115) & (90) & 90 & (72) \\
\hline xii. & $\begin{array}{l}\text { Lateral Cant Angle between } \\
\text { AI-Axis and AI-AS Ridge }\end{array}$ & 10 & $(45)$ & 50 & $(40)$ \\
\hline xiii. & $\begin{array}{l}\text { Lateral Cant Angle between } \\
\text { AI-Axis and VIB }\end{array}$ & 5 & (35) & 50 & 40 \\
\hline xiv. & $\begin{array}{l}\text { Lateral Cant Angle between } \\
\text { Plane of G. Sciatic Notch and VIB }\end{array}$ & 20 & 30 & 25 & 15 \\
\hline
\end{tabular}

vertical iliac buttress along the sagittal plane and along the frontal plan as shown in Fig. 4 are thus measured. The relationships of the lateral cant or inclination of the anterior inferior iliac spine and the anterior border of the iliac blade are schematically shown in Fig.7. The anterior border is strongly inclined in the Australopithecus and Erectus stages, while it is rather erected in the Sapiens stage. In the case of Akashi it is extraor- dinarily erected. On the other hand, the strong inclination of the inferior spine is limited in the Australopithecus stage. Markedly changed characters along the progress of the evolutional stage are shown in Fig. 8.

All these metrical characters indicate that Minatogawa $I$ is intermediate between Neanderthal and Sapiens whereas Akashi is modern.

Statistical analysis 
Table 6. Detailed metrical characters of the innominates from Japan obtained by the methods developed for the present study.

\begin{tabular}{|c|c|c|c|c|}
\hline \multirow{2}{*}{ Item } & \multicolumn{3}{|c|}{ Pleistocene } & \multirow{2}{*}{$\begin{array}{c}\text { Recent } \\
\text { Japanese } \\
\left(\begin{array}{cc}n & s \\
M\end{array}\right)\end{array}$} \\
\hline & $\underset{I}{\text { Minatogawa }}$ & Mikkabi & Akashi & \\
\hline $\begin{array}{l}\text { i. Height of Iliac Blade } \\
\text { (H3 to DIN-DSN Line) }\end{array}$ & (92) & - & (88) & $\begin{array}{c}12 \quad 6.1456 \\
98.3\end{array}$ \\
\hline $\begin{array}{l}\text { ii. Projected Width of Ilium } \\
\left(\mathrm{AS}^{\prime}-\mathrm{PS}^{\prime}\right)\end{array}$ & 154 & - & 124 & $\begin{array}{l}128.8506 \\
146.2\end{array}$ \\
\hline $\begin{array}{l}\text { i : ii. Height-Width Index of } \\
\text { Iliac Blade }\end{array}$ & 60 & - & 71 & $\begin{array}{c}12 \quad 3.7979 \\
67.3\end{array}$ \\
\hline $\begin{array}{l}\text { iii. Width of Iliac Blade Base } \\
\text { (NIN-NSN) }\end{array}$ & 70 & 67 & 62 & $\begin{array}{c}12 \quad 3.9158 \\
70.7\end{array}$ \\
\hline $\begin{array}{l}\text { iv. Width of Iliac Blade Base } \\
\text { (AI-NSN) }\end{array}$ & 70 & 67 & 62 & $\begin{array}{c}12 \quad 4.2817 \\
70.8\end{array}$ \\
\hline $\begin{array}{l}\text { iii : 12. Index of Constriction of } \\
\text { Iliac Blade Base }\end{array}$ & 45 & 一 & 49 & $\begin{array}{c}12 \quad 1.8990 \\
46.8\end{array}$ \\
\hline $\begin{array}{l}\text { v. Acetabulo-auricular } \\
\text { Length }\end{array}$ & 56 & 45 & 41 & $\begin{array}{c}125.7281 \\
48.5\end{array}$ \\
\hline $\begin{array}{l}\text { vi. Thickness of Ischial Body } \\
\left(\mathrm{PAB}-\mathrm{NSN}^{\prime}\right)\end{array}$ & 37 & 33 & 27 & $\begin{array}{l}12 \quad 1.8505 \\
35.8\end{array}$ \\
\hline $\begin{array}{l}\text { vii. Inclination Angle of VIB } \\
\text { to AI-AU Line }\end{array}$ & 93 & 94 & 91 & $\begin{array}{l}127.1026 \\
92.6\end{array}$ \\
\hline $\begin{array}{l}\text { viii. Inclination Angle of VIB } \\
\text { to SAB-SSN Line }\end{array}$ & 97 & 98 & 93 & $\begin{array}{c}12 \quad 8.0731 \\
95.1\end{array}$ \\
\hline $\begin{array}{l}\text { ix. Inclination Angle of VIB } \\
\text { to SAB-AU Line }\end{array}$ & 83 & 80 & 79 & $\begin{array}{c}128.7108 \\
83.7\end{array}$ \\
\hline $\begin{array}{l}\text { x. Inclination Angle of VIB } \\
\text { to DIN-DSN Line }\end{array}$ & 122 & 122 & 116 & $\begin{array}{l}12 \quad 5.4160 \\
120.7\end{array}$ \\
\hline $\begin{array}{l}(v i i+v i i i+i x) / 3 \text {. Average } \\
\text { Inclination Angle of VIB }\end{array}$ & 91 & 91 & 88 & $\begin{array}{l}12 \quad 7.8291 \\
89.8\end{array}$ \\
\hline $\begin{array}{l}\text { xi. Angle between TC-AS Line } \\
\text { and DIN-DSN Line }\end{array}$ & 71 & (75) & 80 & $\begin{array}{c}12 \quad 4.7673 \\
74.0\end{array}$ \\
\hline $\begin{array}{l}\text { xii. Lateral Cant Angle between } \\
\text { AI-Axis and AI-AS Ridge }\end{array}$ & 30 & (30) & -5 & $\begin{array}{c}12 \quad 88.227 \\
33.8\end{array}$ \\
\hline $\begin{array}{l}\text { xiii. Lateral Cant Angle between } \\
\text { AI-Axis and VIB }\end{array}$ & 30 & (25) & 20 & $\begin{array}{c}125.2764 \\
28.8\end{array}$ \\
\hline $\begin{array}{l}\text { xiv. Lateral Cant Angle between } \\
\text { Plane of G. Sciatic Notch and VIB }\end{array}$ & 10 & (13) & 13 & $\begin{array}{c}12 \quad 5.4523 \\
11.5\end{array}$ \\
\hline
\end{tabular}

The sizes of the fossil hominid innomi- selected for the multidimensional scaling. nates are various. The results hitherto They are 9:12 from Table 1 and i: ii, described, however, are rather related to iii : 12, and $\mathrm{x}$ from Table 5 and $6 . \mathrm{OH}-$ the shape. Therefore, it becomes impor- 28 is omitted from this treatment, because tant to observe the pure shape. For this it has inaccurate value of $9: 12$.

reason it is desirable to use metrical char- The results thus obtained are shown in acters without dimension, such as index Fig.9. Australopithecus and Erectus are and angle.

In order to distinguish the evolutional far from Sapiens and the former is farstages, four from such characters are is close to Sapiens. 


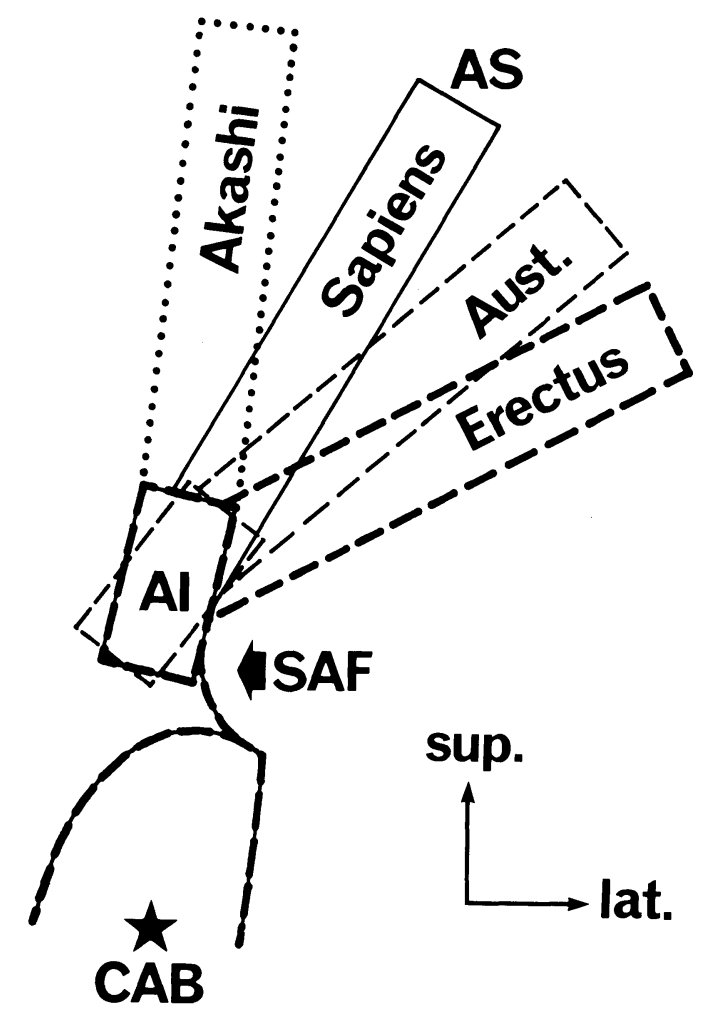

Fig.7. Scheme of various lateral cants of the anterior border of the iliac blade. AS, anterior superior spine; AI, anterior inferior spine; SAF, supraacetabular fossa; CAB, center of acetabulum.
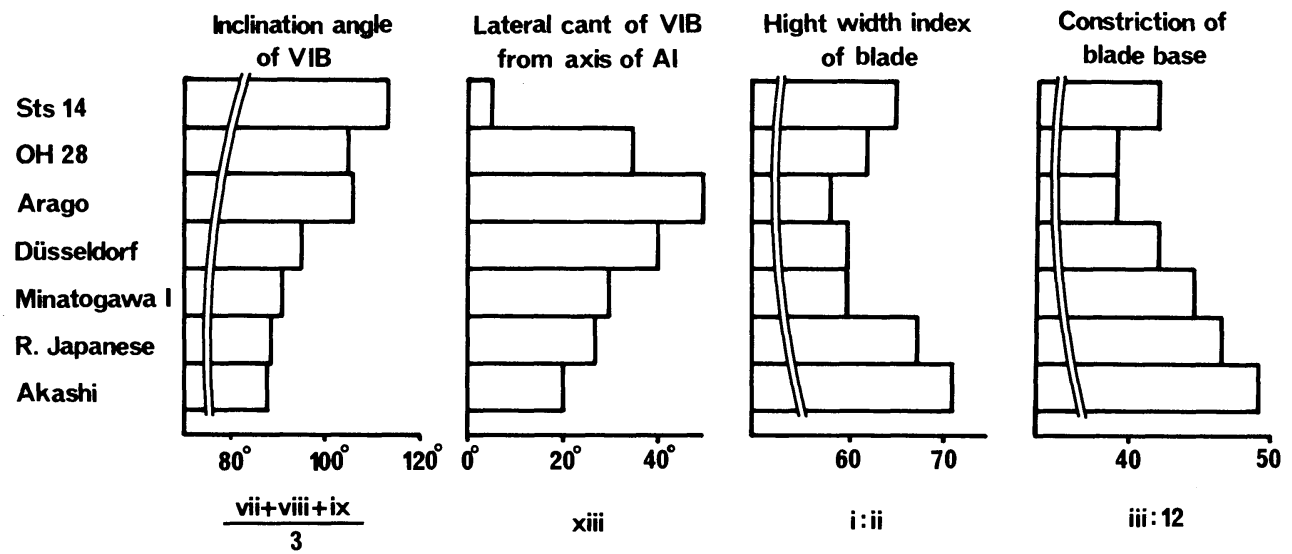

Fig. 8. Evolutional change of main part of metrical characters used in the present study. 


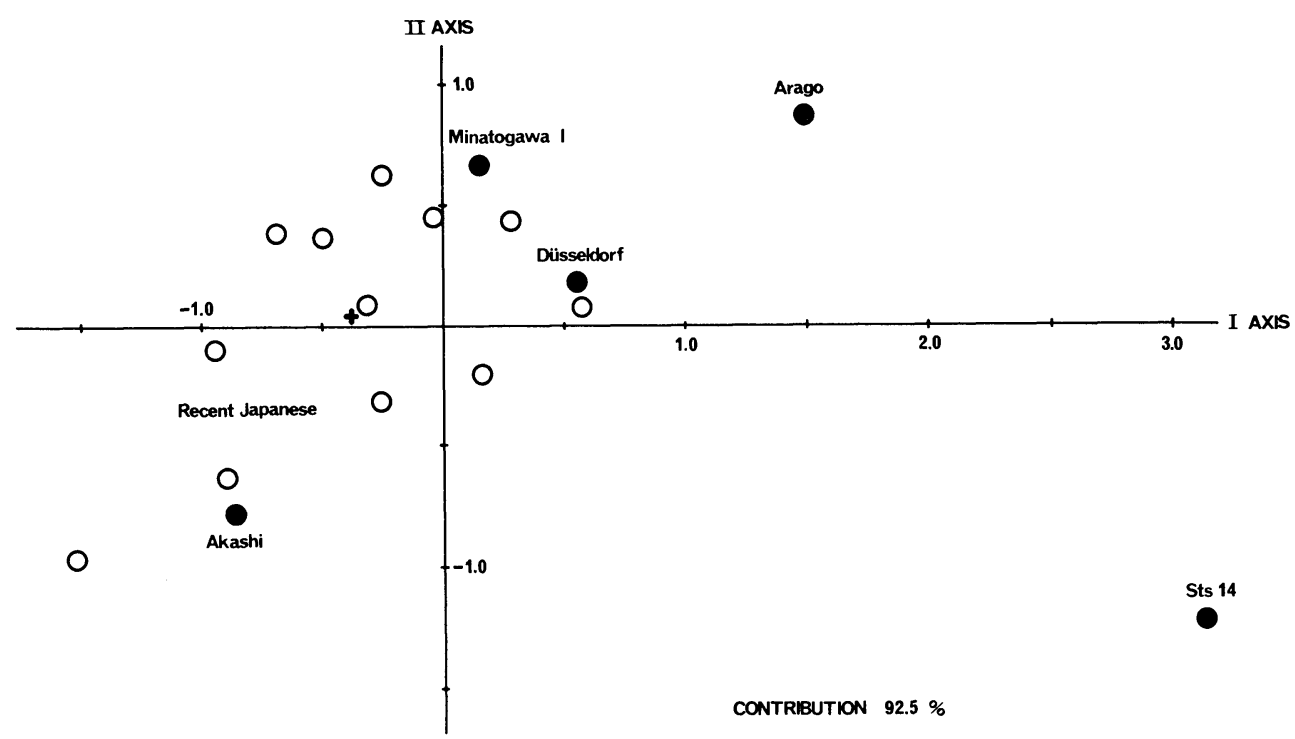

Fig.9. Two-dimensional demonstration of the results obtained from the multidimensional scaling computation using the Euclidean distances calculated from four nondimensional characters (9:12, i: ii, iii: 12 , and $x$, cf. Table 1 and Tables 5 and 6). + indicates the mean position of the twelve Recent Japanese.

Of Japanese fossil specimens, Minatogawa I is somewhat shifted like Düspure shape. This is executed by dividing each length of members of the heptagon seldorf toward the position of the Erectus, by the value of $\mathrm{i}+\mathrm{ii}$ in Tables 5 and 6 . but Akashi is shifted inversely. All in Using the mid-point between DIN and all, both the specimen seems to fall within the region of the Sapiens.

\section{TWO-DIMENSIONAL SHAPE OF ILIAC BLADE}

\section{Simplification of shape}

From the measurements described in Fig.6, the simplified two-dimensional shape of the iliac blade can be drawn on the specimens used in the present study, as shown in Fig. 10. Differences of Australopithecus and Erectus from other specimens seem clear.

Next, the size of these figures is made nondimensional in order to obtain the
DSN as the common origin, these figures are so oriented that the DIN-DSN line becomes horizontal. The figures thus drawn are shown in Fig. 11.

\section{Comparison of simplied shape}

The top of this figure shows the successive change in shape of the iliac blade from the Australopithecus stage to the Sapiens stage. The middle compares Akashi and Minatogawa I with Neanderthal and an example of Sapiens. It shows that these two are rather similar to Sapiens. The bottom compares them with six examples of Recent Japanese, indicating that there is almost no difference. 


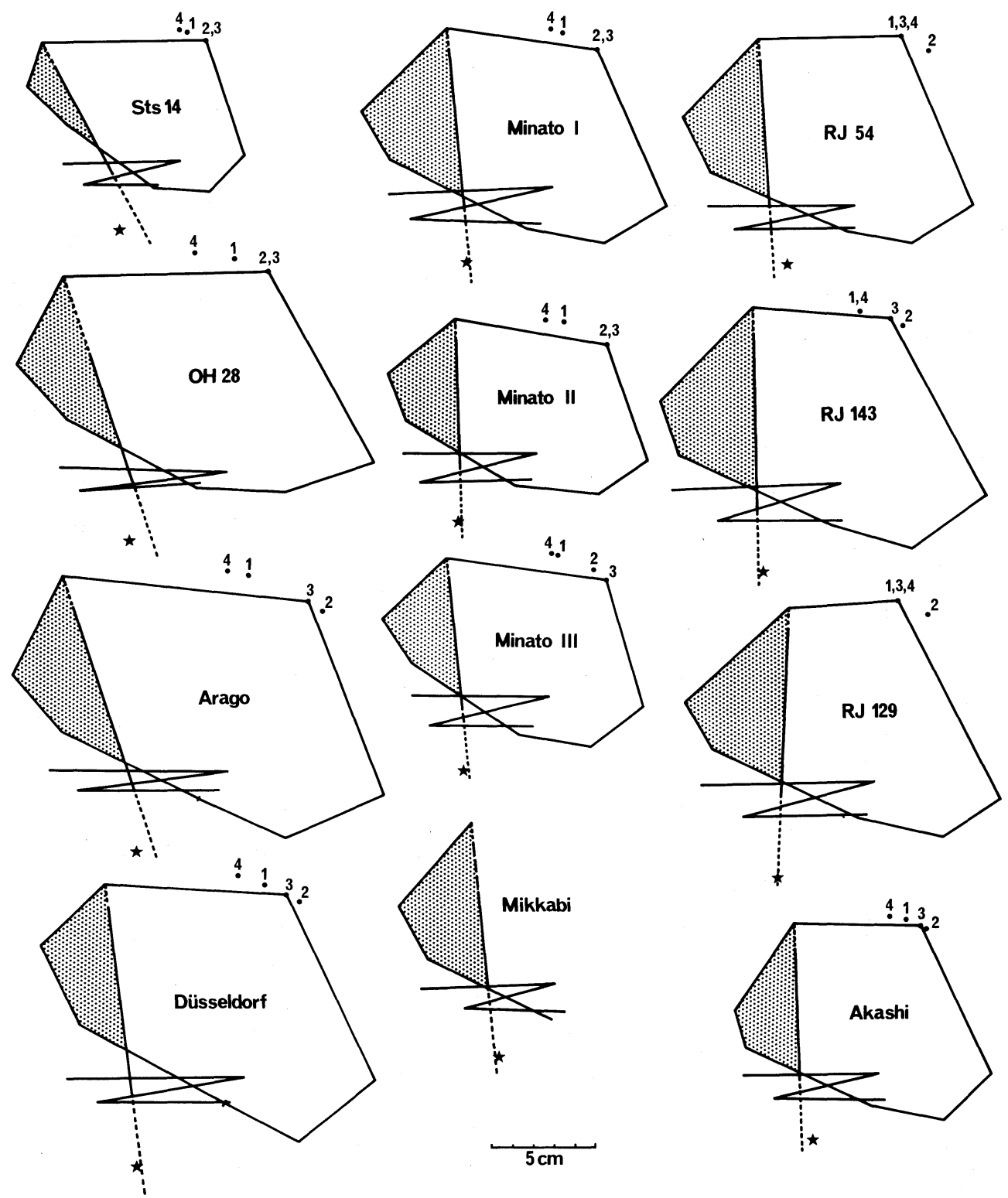

Fig.10. Comparison of the form of the iliac blade by means of the simplified heptagon. 1 to 4 indicate $\mathrm{H} 1$ to $\mathrm{H} 4$ explained in Fig. 6. For other explations see also Fig. 6.

\section{Statistical analysis}

Fig.11 seems to show clear facts, but it is still insufficient, because the distribution due to variation of Sapiens is not observable. For further analysis, each position of intersection was measured based on the two-dimensional coordinate system consisting of the horizontal and vertical axes having the origin at the mid-point between DIN and DSN. The data of two-dimensional positions are used again for the multidimensional scal- 
ing.

The results obtained are shown in Fig. 12. They are fairly similar to the results
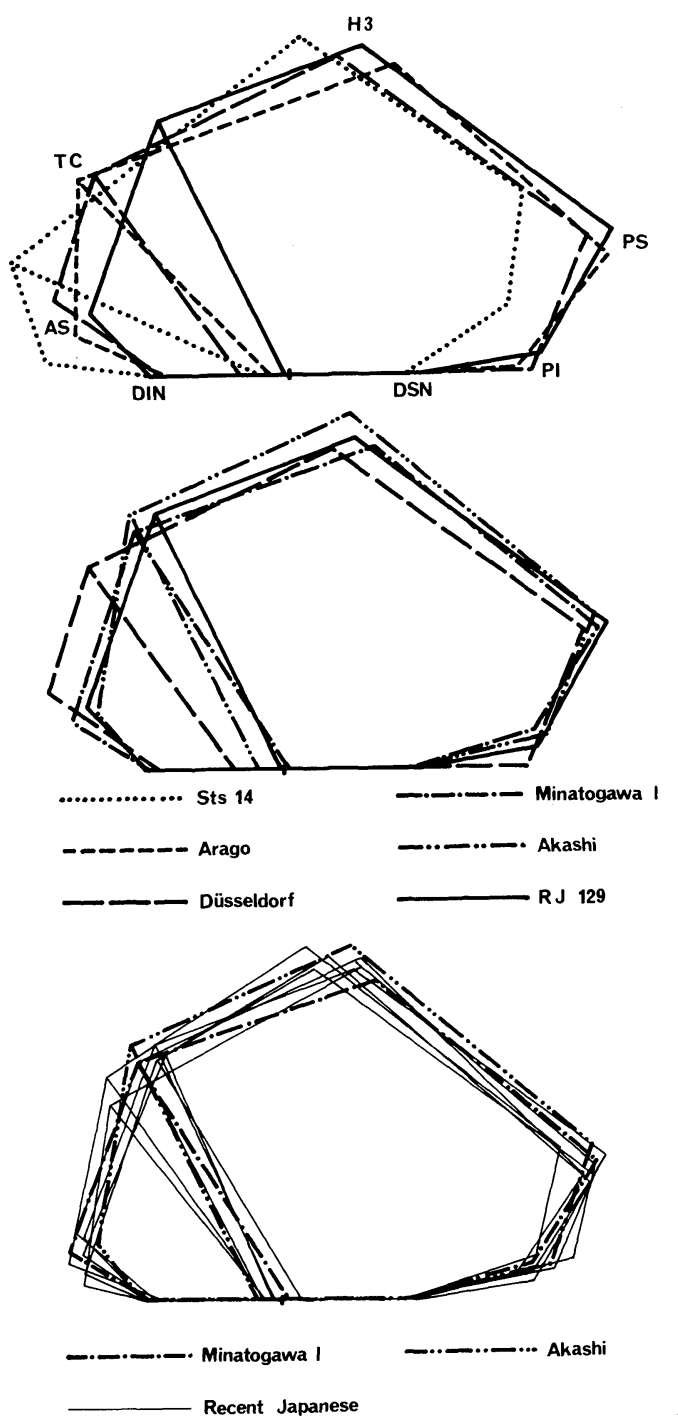

Fig.11. Comparison of the pure shape of the iliac blade represented by the nondimensionally simplified heptagon. Top, Australopithecus, Erectus, Neanderthal and Sapiens; middle, Minatogawa I and Akashi compared with Neanderthal and Sapiens; bottom, Minatogawa I and Akashi compared with six Recent Japanese. shown in Fig. 8. Akashi is located within the distributed area of Sapiens, whereas Minatogawa $I$ is located again in their peripheral area, being rather close to Neanderthal.

\section{DISCUSSION AND CONCLUSION}

\section{Major evolutionary change}

There are almost parallel tendencies in the evolutionary change of morphological characters of the illum from the Erectus stage to the Sapiens stage, which are cleary indicated in Figs. 2,3, 5, 7, 8, 9 and 12.

As for the Australopithecus stage, how ever, some characters fit well onto the extension of these tendencies, but the others do not, namely, lateral cant of the iliac blade, relative width of the blade, constriction of the blade base and so on. This rather peculiar feature of the Australopithecus ilium from the evolutionary point of view is also suggested by the peculiar position in the distribution diagrams of Figs. 9 and 12 . Further studies are necessary to clarify this problem.

\section{Japanese Pleistocene innominates}

Based on his study on the morphological features of the Akashi innominate bone, HASEBE (1948) maintained that this bone must be of a man in the Erectus stage. His assertion depended on several characteristics observable in this specimen. However, these characteristics are all modern according to the present study except for the smallness. None seems archaic.

In the case of the Mikkabi innominate, Suzuki (1962) pointed out some characters 


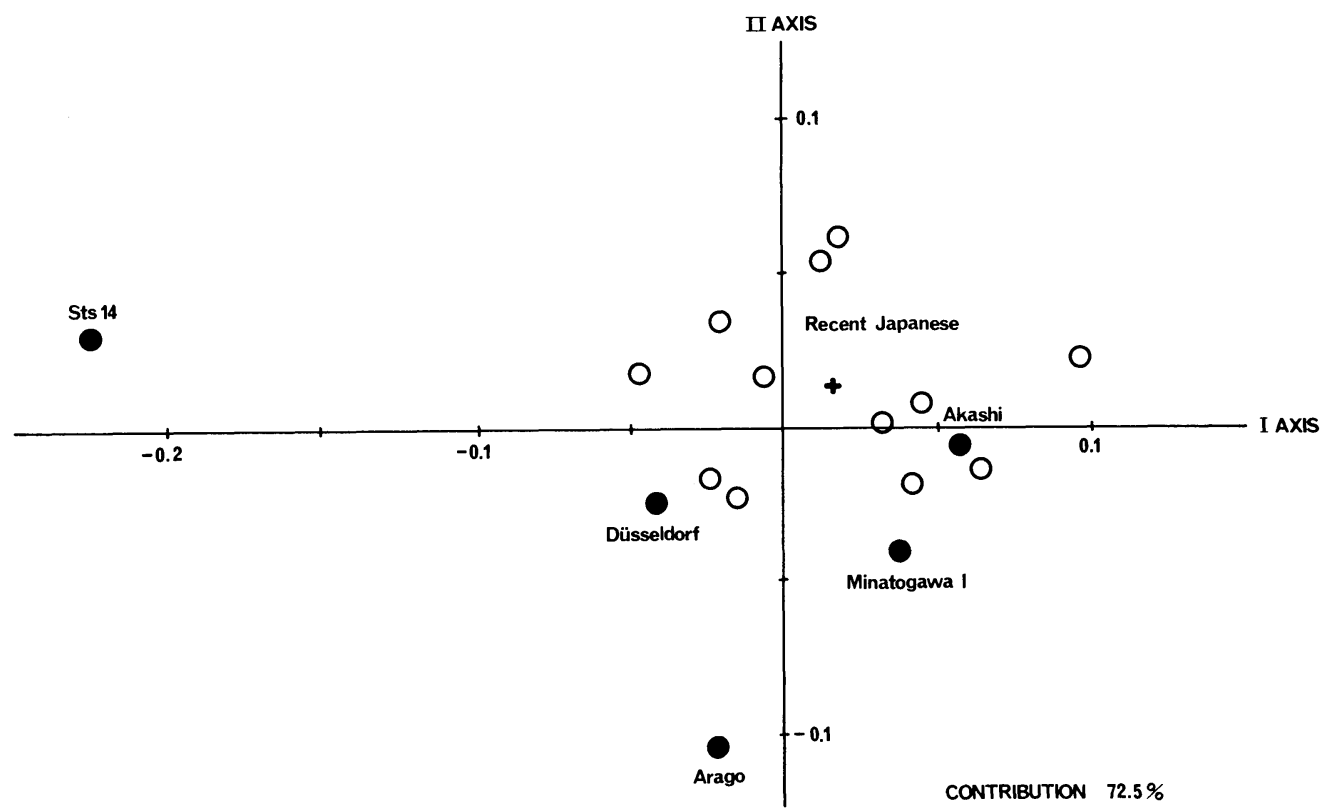

Fig.12. Two-dimensional demonstration of the results obtained from the multidimensional scaling computation using the Euclidean distances calculated from the coordinate values of all the intersecting points of the heptagon. + indicates the mean position of the twelve Recent Japanese.

different from those of Akashi. Accord- the stratigraphical facts (WATANABE et ing to the present study, they are rather al, 1962) and the paleontological facts archaic characters indicating a primitive (TAKAI, 1962), as well as the results of Sapiens.

It can be concluded that the Akashi the fluorine test (TANABE, 1962), are taken man is neither Erectus nor Neanderthal nor Pleistocene Sapiens. $\mathrm{He}$ is probably a Japanese of the historic age and could possibly be a modern Japanese. This morphological fact indicates that the stratigraphical doubts are valid.

The Minatogawa man is in all morphological respects an archaic Sapiens. Judging from not only the morphological facts but also the chronological facts (SUZUKI, 1982), he must surely be a Pleistocene Sapiens. It can also be considered from the morphological facts that the into consideration together with the morphological facts, the Mikkabi man must also be a Pleistocene Sapiens.

In the case of the Minatogawa man further detailed archaic characters can be seen in male and female, because innominates were well preserved in this case (BABA and ENDO, 1982).

\section{ACKNOWLEDGMENT}

The present authors express their sincere thanks to Professor de Lumley, for his permission to use the Arago innominate cast for comparison.

Mikkabi man is an archaic Sapiens. When 


\section{REFERENCES}

BABA, H. and ENDo, B., 1982: Chapt. 4. Postcranial skeleton of the Minatogawa Man. In: The Minatogawa man. The Upper Pleistocene Man from the Island of Okinawa (eds. H. SuzuKI and K. Hanihara). Bul. Univ. Mu. Univ. Tokyo, 19: 61-195.

Boul, M., 1911-13: L'homme fossile de La Chapelle-aux-Saints. Ann. Paléont., 6,7,9.

DAY, M., 1971: Postcranial remains of Homo erectus from Bed IV, Olduvai Gorge, Tanzania. Nature, 232 : 383-387.

Endo,B. and KImURA, T., 1970: Postcranial skeleton of the Amud man. In: Amud man and his cave site (eds. H. SUZUKI and F. TAKAI): 231-406. The Univ. Tokyo/Keigaku.

Fischer, R., 1958: Statistical method for research workers. 13th Editon. Oliver and Boyd, London.

Fuhlrot, C. und SchaAfFhausen, H., 1857 : Correspondenzblatt des naturhistorischen Vereins der preussischen Rheinlande und Westphalens. Verh. naturh. Ver, preuss. Rheinl., 14: 50-52.

HASEBE, K., 1948: A human coxal bone from Lower Pleistocene deposit at Nishiyagi, Akashi. J. Anthrop. Soc. Nippon, 60: 32-36. (In Japanese)

〔長谷部言人, 1948 : 明石市附近西八木最新世前期 堆積出土人類腰骨 (石高型) の原始性に就いて。人 類誌 $60: 32$-36頁. ]

Kishine, T., 1977: Theory and application of statistics. Yokendo, Tokyo.

〔岸根卓郎, 1977 : 理論・応用統計学. 養賢堂〕

LEAKEY, M., 1971: Discovery of postcranial remains of Homo erectus and associated artifacts in Bed IV at Olduvai Gorge, Tanzania. Nature, 232: 380-383.

de Lumley, H., 1979: L'homme de Tautavel. Dossiers de l'Archéol., 36: 54-59.

Masuyama, M., 1943: Test for the rejection of observed vectors and its application to medicine. Biol. Med., 3:291-293. (In Japanese) 〔増山元三郎 .1943：ベクトル棄却検定法とその医 学的応用. 医学々生物学 3:291-293頁]

McCown, T. and KeITH, A., 1939: The stone age of Mount Carmel. Vol.2. The fossil human remains from the Levalloiso-Mousterian. Clarendon, Oxford.

Miyamoto,H., 1927: Anthropologischen Untersuchungen uber das Skelett der rezenten Japaner. III. Das Becken. J. Anthrop. Soc. Nippon, 42 (Suppl.):1-58. (In Japanese with German title)

NAORA, N., 1936: Pleistocene in Japan and origin of man. Minerva, 1:147-156. (In Japanese)

〔直良信夫，1936：日本最新世と人類発達史.ミネ ルヴァ $1: 147-156$ 頁]

Robinson, J., 1972: Early hominid posture and locomotion. Univ. Chicago Press, Chicago and London.

SuZUKI, H., 1962: 1. Skeletal remains of Mikkabi man. In: Mikkabi man and the fossil bearing deposits from Tadaki limestone quarry at Mikkbi, Central Japan (by H.SuzUKI et al). J. Anthrop. Soc. Nippon, 70: 1-20. (In Japanese with English summary)

SuzUKI, H., and HANIHARA, K., (eds.) 1982: The Minatogawa Man. The Upper Pleistocene Man from the Island of Okinawa. Bul. Univ. Mus. Univ. Tokyo, No. 19/Univ. Tokyo Press. Suzuki, H., Takar, F., Watanabe, H., Endo, B., Омото, K., Hasegawa, Y., Chinzer, K. and TANABE,G., 1962: Mikkabi man and the fossil-bearing deposits from Tadaki limestone quarry at Mikkabi, Central Japan. J. Anthrop. Soc. Nippon, 70: 1-48. (In Japanese with English summary)

SuzuKI, H., TAKaI, F., Hasegawa, Y., ChINZEI, K., TANABE, G. and ENDO,B., 1966: Hamakita man and the site of Nekata limestone quarry at Hamakita. J. Anthrop. Soc. Nippon, 74: 101-176. (In Japanese with English summary)

Suzuki, H., and TANABe, G., 1982: Chapt. 1. Introduction. In: The Minatogawa Man. The Upper Pleistocene Man from the Island of Okinawa (eds. H. SuzUKI and K. HANIHARA). Bul. Univ. Mus. Univ. Tokyo, 19: 1-5.

Tавата, T., 1928: Anthropologische Untersuchungen über das Menschenskelett aus Tsukumo-Muschelhaufen. J. Anthrop. Soc. Nip. 
pon, 43 (Supp.): 740-814. (In Japanese with German title)

TAKAI, F., 1962: Vertebrate fossils from the Tadaki formation. In: Mikkabi man and the fossil-bearing deposits from Tadaki limestone quarry at Mikkabi, Central Japan (by $\mathrm{H}$. SUzUKI et al). J. Anthrop. Soc. Nippon, 76: 3640. (In Japanese with English summary)

TANABE, G., 1962: Fluorine contents of human bones found at Pleistocene deposits of Mikkabi.In: Mikkabi man and the fossil-bearing deposits from Tadaki limestone quarry at Mikkabi, Central Japan (by H. Suzuki et al). J. Anthrop. Soc. Nippon, 70: 41-45. (In Japanese with English summary)

Watanabe, H., Endo, B. and Oмото, K., 1962: The limestone-fissure site of Mikkabi. In: Mikkabi man and the fossil-bearing deposits from Tadaki limestone quarry at Mikkabi, Central Japan (by H. SuzuKi et al). J. Anthrop. Soc. Nippon, 70: 21-28. (In Japanese with English summary)

Watanabe, N., 1970: Early Pleistocene in view of anthropology with special reference to Nipponanthropus. Quatern. Res., 9: 176183. (In Japanese with English summary)

(Received June 10, 1982)
Note 1. (from Masurama, 1943)

Let a sample consisting of $\boldsymbol{x}_{1}, \boldsymbol{x}_{2}, \cdots \boldsymbol{x}_{m}$ be from a population, where $\boldsymbol{x}_{m}=\left(x_{m_{1}}, x_{m_{2}}, \cdots x_{m k}\right)$. Let $S_{i j}=\sum_{m=1}^{n}\left(x_{m i}-\bar{x}_{i}\right)\left(x_{m j}-\bar{x}_{j}\right)$ and

$\left[S_{i j}\right]^{-1}=\left[T_{i j}\right]$.

The equation for test of the specimen $\boldsymbol{x}_{0}$ is $F_{o h_{s}}=\frac{(N-k) N}{k(N+1)} \sum_{i=1}^{k} \sum_{j=1}^{k} T_{i j}\left(x_{o i}-\bar{x}_{i}\right)\left(x_{o j}-\bar{x}_{j}\right)$,

where $d f_{1}=k$ and $d f_{2}=N-k$.

Note 2. (from Fischer, 1958 and Kishine, 1977)

Let a sample consist of $x_{1}, x_{2}, \cdots x_{n}$ and let $m_{i}=\sum_{j=1}^{n}\left(x_{j}-\bar{x}\right)^{i} / n$. Then let

$k_{2}=\frac{n}{n-1} m_{2}, k_{3}=\frac{n^{2}}{(n-1)(n-2)} m_{3}$,

$k_{4}=\frac{n^{2}\left\{(n+1) m_{4}-3(n-1) m_{2}^{2}\right\}}{(n-1)(n-2)(n-3)}$.

The cumulants are $g_{1}=\frac{k_{3}}{k_{2}{ }^{3 / 2}}$ and $g_{2}=\frac{k_{4}}{k_{2}{ }^{2}}$.

The variances of $g_{1}$ and $g_{2}$ are

$$
\sigma_{g_{1}}{ }^{2}=\frac{6 n(n-1)}{(n-2)(n+1)(n+3)} \text { and }
$$

$\sigma \sigma_{2}{ }^{2}=\frac{24 n(n-1)^{2}}{(n-3)(n-2)(n+3)(n+5)}$.

Calculate $z$ as

$$
z_{1}=\frac{\left|g_{1}\right|}{\sigma g_{1}} \text { and } z_{2}=\frac{\left|g_{2}\right|}{\sigma g_{2}} \text {. }
$$

Read probabilities of $p_{1}$ and $p_{2}$ from normal distribution table at $z_{1}$ and $z_{2}$ respectively. Let $\alpha$ be the level of significance.

If $p_{1}>\alpha$ and $p_{2}>\alpha$,

the sample is normally distributed.

* Many researchers regard this fossil as a precursor of the European Neanderthal. The term Homo erectus is used in a wide sense in the present paper. 
日本更新世人寛骨の形態学的研究

一とくに明石人寛骨を含めて——

遠藤萬里 ${ }^{1)}$ ・馬場悠男 ${ }^{2)}$

1) 東京大学理学部人類学教室

2) 独協医科大学解剖学教室

日本における更新世人類の化石は少なく，しかも近年発見された港川人の場合を除けば，さまざまな骨の破

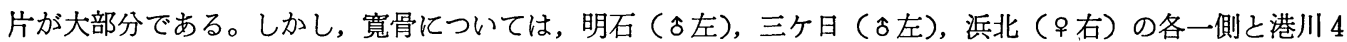
個体（１１個体，ㅇ 3 個体）の両側を数えるととができる。浜北は残存部が小さ過ぎるが，他は少くとも腸骨 について他の人類とあるいは相互の形態学的比較検討が可能である。また明石と港川については，少くとあ腸 骨の全貌を推察するととができる。他方，現在ではアフリカやヨーロッパで Australopithecus, Erectus， Neanderthal の各段階の寛骨が発見されていて，その模型が入手可能となっている。てれらあ同様に，少く とも腸骨の全貌を推察しうるあのである。

このような状況において，観察の対象となりうる男性寬骨，明石，三ヶ日，港川 I を更新世化石寬骨模型お よび現代日本人寬骨と比較し，それらの形態学的特徴を明らかにすることを試みた。なお明石についてはその 包含層について疑問が多い（渡辺，1970）。

比較資料として，化石寬骨には Sts-14 (Australopithecus) OH-28 (Erectus), Arago (Erectus), Düsseldorf (Neanderthal) の模型を，現代日本人には東京太学総合研究資料館および独協医科大学所蔵の 男性寬骨左側12個体を用いた。また計測值比較資料として，宮本（1927）の現代幾内日本人資料と田幡（1928） の津雲縄文時代人資料を用いた。

上記の化石寬骨模型および日本更新世人寬骨からあらたに黄色石膏によるレプリカを作成し, 久損部は白色 石膏で補なって復原した。これは先に述べた腸骨全体の形を推察するとともに，とすすれば古さを强調するよ うに見える原標本の色調によって生じやすい観察の片寄りを防ぐためである。

上記の全標本を通観すると，日本の更新世人の寬骨はいづれあ現代日本人に最む類似する。すなわち，すべ て Sapiens 隹属すると考えられる。

ここで, 通常の計測法により可能な計測値と現代幾内日本人の同種の計測值を統計的に比較する。方法は幾 内人をべクトル母集団とし, 日本更新世人之津雲縄文人 5 個体の計測值ベクトルを棄却検定（増山1943）する ことによる。結果は Table 3 の通りである。全津雲人之明石人は萧却されず現代日本人母集団に属している。 少くとも完新世日本人といえる。とれに反し, 港川人Iは完全に棄却され他の集団に属することがわかる。同 じ計測項目について幾内人の標準偏差をむちいた Shape distance で幾内人 30 個体, 津雲縄文人 5 個体, 明 石人, 港川人Iの行列を作り, てれに多次元尺度法を適用する。結果は上記のむのにほぼ等しく，しかむ明石 人は港川人 I とかけ離れているととがわかる（Fig.1）。

寬骨の表面に観察できる諸特徵は Figs. 2, 3, 5, 7, Table 4 の通りである。これらには進化段階と平行し て変化する特徵が多く, それらから判断すると港川 I, 三ヶ日は Neanderthal 的な古い Sapiens と考えら れるが，明石は現代的である。

ここで詳細な計測法を設定して適用してみる。そのなかから無名数值を選しで形状を比較する。この場合は 個体間ユークリッド距離にもとづく多次元尺度法を適用する。結果は Fig. 9 亿見られるように港川 I は化石 人類的で明石は現代人的であるてとを示している。

腸骨の形状を単純化 (Fig. 6 参照) して 7 角形とするとFig. 10 のようになるが，乙れを無名数化して比較 すると Fig.11のように明石あ港川 I す Sapiens 的である。これらに共通原点を与えて7角形各頂点および 交点座標值を測り，ユークリッド距離による多次元尺度法を適用しても, 結果 (Fig. 12) は今迄と同じく, 明石は新しく港川は化石人的になる。

結局, 明石人寬骨は縄文以降現代までのいづれかの時代の日本人寬骨であり，港川Ｉと三ケ日の寬骨は更新 世 Sapiens の寬骨之考えるのが妥当である。 